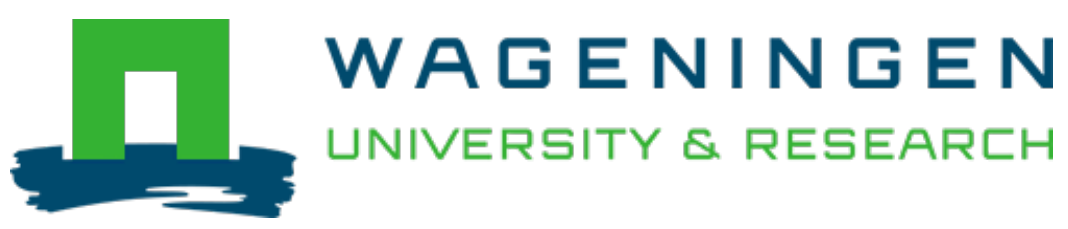

\title{
Disentangling drivers of soil microbial potential enzyme activity across rain regimes : An approach based on the functional trait framework
}

\author{
Soil Biology and Biochemistry \\ Piton, Gabin; Foulquier, Arnaud; Martínez-García, Laura B.; Legay, Nicolas; Hedlund, Katarina et al \\ https://doi.org/10.1016/j.soilbio.2020.107881
}

This article is made publicly available in the institutional repository of Wageningen University and Research, under the terms of article $25 \mathrm{fa}$ of the Dutch Copyright Act, also known as the Amendment Taverne. This has been done with explicit consent by the author.

Article 25 fa states that the author of a short scientific work funded either wholly or partially by Dutch public funds is entitled to make that work publicly available for no consideration following a reasonable period of time after the work was first published, provided that clear reference is made to the source of the first publication of the work.

This publication is distributed under The Association of Universities in the Netherlands (VSNU) 'Article $25 \mathrm{fa}$ implementation' project. In this project research outputs of researchers employed by Dutch Universities that comply with the legal requirements of Article $25 \mathrm{fa}$ of the Dutch Copyright Act are distributed online and free of cost or other barriers in institutional repositories. Research outputs are distributed six months after their first online publication in the original published version and with proper attribution to the source of the original publication.

You are permitted to download and use the publication for personal purposes. All rights remain with the author(s) and / or copyright owner(s) of this work. Any use of the publication or parts of it other than authorised under article $25 \mathrm{fa}$ of the Dutch Copyright act is prohibited. Wageningen University \& Research and the author(s) of this publication shall not be held responsible or liable for any damages resulting from your (re)use of this publication.

For questions regarding the public availability of this article please contact openscience.library@,wur.nl 


\title{
Disentangling drivers of soil microbial potential enzyme activity across rain regimes: An approach based on the functional trait framework
}

\author{
Gabin Piton $^{\text {a, }, \text {, Arnaud Foulquier }}{ }^{\text {, }}$ Laura B. Martínez-García ${ }^{\text {b }}$, Nicolas Legay ${ }^{c}$, \\ Katarina Hedlund ${ }^{\mathrm{d}}$, Pedro Martins da Silva ${ }^{\mathrm{e}}$, Eduardo Nascimento ${ }^{\mathrm{e}}$, Filipa Reis ${ }^{\mathrm{e}}$, \\ José Paulo Sousa $^{\mathrm{e}}$, Gerlinde B. De Deyn ${ }^{\mathrm{b}}$, Jean Christophe Clement ${ }^{\mathrm{f}}$ \\ ${ }^{\text {a } U n i v . ~ G r e n o b l e ~ A l p e s, ~ U n i v . ~ S a v o i e ~ M o n t ~ B l a n c, ~ C N R S, ~ L E C A, ~ 38000, ~ G r e n o b l e, ~ F r a n c e ~}$ \\ ${ }^{\mathrm{b}}$ Soil Biology Group, Wageningen University \& Research, P.O. Box 47, 6700, AA Wageningen, the Netherlands \\ ${ }^{\mathrm{c}}$ INSA Centre Val de Loire, Université de Tours, CNRS, UMR 7324 CITERES, 37200, Tours, France \\ ${ }^{\mathrm{d}}$ Department of Biology, Lund University, SE-223 62, Lund, Sweden \\ e Centre for Functional Ecology, Department of Life Sciences, University of Coimbra, 3000-456, Coimbra, Portugal \\ ${ }^{\mathrm{f}}$ Univ. Savoie Mont Blanc, INRAE, CARRTEL, 74200, Thonon-Les-Bains, France
}

\section{A R T I C L E I N F O}

\section{Keywords:}

Bacteria

Climate change

Enzymatic stoichiometry

Fungi

PLFA

Structural equation model

\begin{abstract}
A B S T R A C T
The functional trait framework provides a powerful corpus of integrated concepts and theories to assess how environmental factors influence ecosystem functioning through community assembly. While common in plant ecology, this approach is under-used in microbial ecology. After an introduction of this framework in the context of microbial ecology and enzymology, we propose an approach 1) to elucidate new links between soil microbial community composition and microbial traits; and 2) to disentangle mechanisms underlying "total" potential enzyme activity in soil (sum of 7 hydrolase potential activities). We address these objectives using a terrestrial grassland ecosystem model experiment with intact soil monoliths from three European countries (Switzerland, France and Portugal) and two management types (Conventional-intensive and Ecological-intensive), subjected to 4 rain regimes (Dry, Wet, Intermittent and Normal) under controlled conditions in a common climate chamber. We found tight associations between proxies of microbial ecoenzymatic community-weighted mean traits (enzymatic stoichiometry and biomass-specific activity) and community composition, bringing new information on resource acquisition strategy associated with fungi, Gram positive and Gram negative bacteria. We demonstrate that microbial biomass explained most of the total enzyme activity before altered rain regimes, whereas adjustments in biomass-specific activity (enzyme activity per unit of microbial biomass) explained most variation under altered rain regime scenarios. Furthermore, structural equation models revealed that the variation of community composition was the main driver of the variation in biomass-specific enzyme activity prior to rain perturbation, whereas physiological acclimation or evolutionary adaptation became an important driver only under altered rain regimes. This study presents a promising trait-based approach to investigate soil microbial community response to environmental changes and potential consequences for ecosystem functioning. We argue that the functional trait framework should be further implemented in microbial ecology to guide experimental and analytical design.
\end{abstract}

\section{Introduction}

Theoretical framework based on the functional trait concept provides a wide corpus of integrated concepts and theories at different levels to address organisms' adaptation, community assembly and ecosystem functioning (Lavorel and Garnier, 2002; Diaz et al., 2007; Violle et al., 2007). Functional traits are defined as any physiological, morphological, phenological or genomic feature, measured at the individual level, and affecting the fitness or function of an organism (Violle et al., 2007; Krause et al., 2014). Integrated at the community level, functional traits underlie the community functional composition often characterized by the community weighted mean (CWM) trait and the trait diversity (Diaz et al., 2007; Violle et al., 2007). These emergent properties at the community level are controlled by mechanisms at the

\footnotetext{
* Corresponding author.

E-mail address: gabinpiton@gmail.com (G. Piton).
} 
individual (physiological acclimation), population (adaptation) and community (species turnover) scales (Violle et al., 2007) and they are considered as major drivers of ecosystem functioning (Grime, 1998; Petchey and Gaston, 2006; Diaz et al., 2007). Hence, the linkages between response traits (controlling organism response and adaptation to environmental changes) and effect traits (controlling organism effect on ecosystem functioning), and their integration at the community level, provide a mechanistic basis to understand community assembly and cascading effects on ecosystem functioning (Lavorel and Garnier, 2002; Litchman et al., 2015) (Fig. 1). Such multiscale integrated framework is essential to correctly interpret complex ecological data. However, functional trait framework has hardly been used in microbial ecology and further studies are required to develop how it can be successfully used for soil microbial communities (Piton et al., 2020).

Plant and microbial traits associated with resource acquisition are both response and effect traits (Lavorel and Garnier, 2002; Litchman et al., 2015), making them promising candidates for inclusion into mechanistic models of ecosystem functioning (Allison, 2012). Extracellular decomposition of organic matter and subsequent assimilation of its depolymerized compounds are central in the resource acquisition strategies of heterotrophic soil microbes (Sinsabaugh and Follstad Shah, 2012). Traits associated with extracellular enzyme production (ecoenzymatic traits) and the uptake of nutrients are probably key in microbial physiological and evolutionary trade-offs (Malik et al., 2019a) (Fig. 1). Indeed, the production of extracellular enzymes bears high energy and nitrogen (N) costs for microbes (Frankena et al., 1988; Allison et al., 2010), at the expense of the investment in other metabolic pathways such as growth, cellular maintenance and stress tolerance (Malik et al., 2019a; Ramin and Allison, 2019). Hence, it has been proposed that oligotrophic microbial species in resource-poor environments invest more in extracellular enzymes to cope with low resource availability compared to copiotrophic species with a growth oriented strategy dominating in resource-rich environments (Fontaine et al., 2003; Fierer et al., 2007). Trade-offs also exist between the production of different enzymatic classes since enzymes should match with substrate availability, while satisfying the nutritional need of the microbial cell (Fig. 1). Biomass stoichiometry is relatively constrained in heterotrophic microbes (Fanin et al., 2013; Zechmeister-Boltenstern et al., 2015), with high biomass $\mathrm{C}: \mathrm{N}$ and $\mathrm{N}: \mathrm{P}$ ratios reported in fungi relative to bacteria and in oligotrophic microbes relative to copiotrophic ones (Fierer et al., 2007; Strickland and Rousk, 2010; Litchman et al., 2015). To match these stoichiometric constraints, the resource allocation model (Sinsabaugh et al., 1993) predicts microbes to optimize the enzyme production for $\mathrm{C}, \mathrm{N}$ and $\mathrm{P}$ acquisition toward the most limiting element to maximize their fitness. Following this theory, enzymatic stoichiometry, that is the relative investment by microbes for $\mathrm{C}, \mathrm{N}$ or $\mathrm{P}$ acquisition enzymes (Sinsabaugh et al., 2009), can be considered as a proxy of the resource acquisition strategy that should be adapted to the nutritional constraint on microbial communities. Oligotrophic microbial communities dominating nutrient poor soils are expected to direct their resource acquisition strategy toward nutrient ( $\mathrm{N}$ and $\mathrm{P}$ ) acquisition, whereas copiotrophic microbes should display an opposed stategy (C acquisition) in nutrient rich soils. However, recent empirical results (Rosinger et al., 2019) challenge this theory and suggest that the nutritional constraint is not the only factor controlling enzymatic stoichiometry.

Measuring functional traits, requires measurement at the individual level, which is very challenging for microbes (Martiny et al., 2015). However, Piton et al. (2020) demonstrated that measuring biomass-specific potential enzyme activity (potential activity per unit of microbial biomass) and enzyme stoichiometry give a direct approximation of community-weighted mean (CWM) traits representative of the dominant strategy in the microbial community. Using such indicators, Malik et al. (2019c) and Piton et al. (2020) observed decreases in mass-specific extracellular potential enzyme activity along soil resource gradients. Their results indicate that oligotrophic microbes invest more in the production of extracellular enzymes as compared to copiotrophic

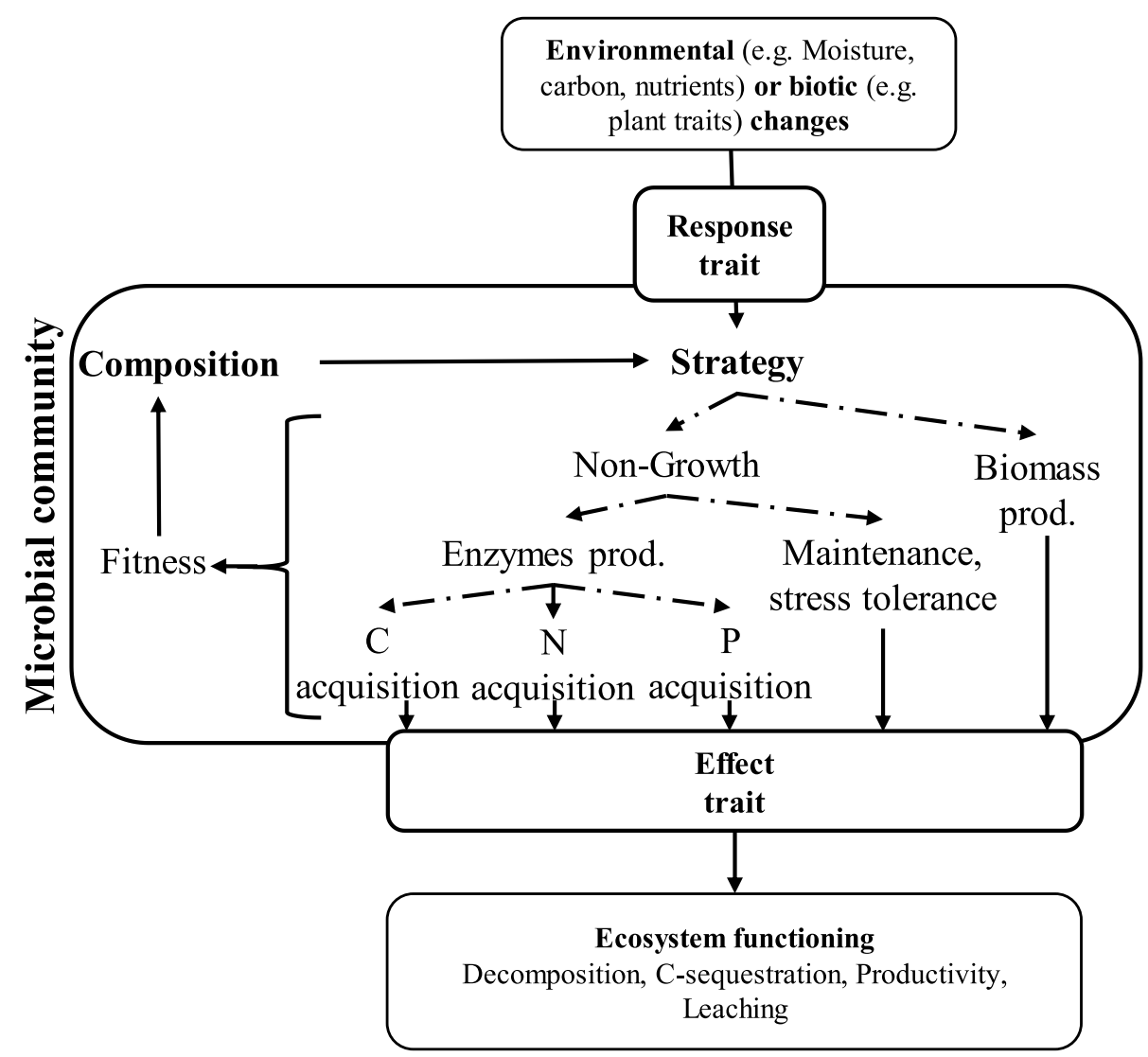

Fig. 1. Response-effect trait model (Lavorel and Garnier, 2002) presenting linkages between response traits (organisms response to environmental changes) and effect traits (organisms effect on ecosystem functioning), adapted for soil microbial community, demonstrating the central position of ecoenzymatic traits (enzyme production for $\mathrm{C}, \mathrm{N}$ and $\mathrm{P}$ acquisition) and biomass stoichiometry $(\mathrm{C} / \mathrm{N} / \mathrm{P})$ in evolutionary and/or physiological trade-off (dotted arrows, Malik et al., 2019a) affecting fitness and community composition, and microbial community effect on ecosystem functioning. 
ones, with these extracellular enzymes especially oriented toward nutrient acquisition (especially P in Piton et al., 2020), consistent with theoretical expectation (Sinsabaugh et al., 1993; Fontaine et al., 2003; Malik et al., 2019a). Consequently, ecoenzymatic CWM traits (biomass-specific activity and enzymatic stoichiometry) are promising candidates to understand how the response of soil microbial communities to environmental changes and its cascading effect on ecosystem functioning.

Extracellular enzyme activity in soils is central for ecosystem functioning as it controls decomposition and mineralization of soil organic matter (Schimel and Bennett, 2004; Bengtson and Bengtsson, 2007). Firstly, this activity depends on the enzyme concentrations in soil and their catalytic properties (e.g. the catalytic turnover rate representing the number of substrates molecules converted to product per enzyme per unit of time). These two parameters drive the extracellular enzymatic potential activity $\left(\mathrm{V}_{\max }\right)$, commonly measured under laboratory condition without constraint of substrates concentration and diffusion, often at a single temperature and a single $\mathrm{pH}$ (Wallenstein and Weintraub, 2008). The realized in situ activity is more difficult to assess but can be modelled, based on this potential activity and the environmental conditions (Wallenstein and Weintraub, 2008; Steinweg et al., 2012; Allison and Goulden, 2017).

Total extracellular enzyme potential activity is controlled by microbial mechanisms scaling from individual to community level (Sinsabaugh, 2005; Burns et al., 2013). Extracellular enzymes are broadly produced among soil microbes (Allison et al., 2007a; Vranova et al., 2013), so that soil enzyme potential activity is assumed to be firstly controlled by the microbial biomass (Kivlin et al., 2013). However, a decoupling between microbial biomass and enzyme potential activity can be induced by enzyme stabilization on inorganic surfaces and organic colloids and persistence after the death of their producers (Nannipieri et al., 2018), or through differences among microbes in extracellular enzyme production per unit of microbial biomass (Allison et al., 2007b; Burns et al., 2013; Kivlin et al., 2013; Steinweg et al., 2013). Variations in the biomass-specific enzyme activity measured at the community level (the CWM trait) can emerge both from changes in community composition (Li et al., 2019), as well as from the community members' physiological acclimation to environmental changes (Schimel et al., 2007) or evolutionary adaptation (Allison et al., 2018).

Today with novel molecular and culturing techniques, there is evidence for a large variation of enzyme production across microbial taxa (Lladó et al., 2016; Manoharan et al., 2017; Žifcáková et al., 2017). For instance, at broad taxonomic scale, a more important production of enzymes for fungi is expected compared to bacteria, explaining their succession during litter decomposition (Sinsabaugh, 2005). Nevertheless, the importance of bacterial enzyme activity in soils has been shown (Manoharan et al., 2017; López-Mondéjar et al., 2019). Several studies also indicate a variation in enzymatic investment within bacterial and fungal groups (Lladó et al., 2016; Pierre-Emmanuel et al., 2016). Gram positive and Gram negative bacteria are considered as oligotrophic and copiotrophic respectively (Fierer et al., 2007; Fanin et al., 2018). Gram positive bacteria use more recalcitrant carbon (C) compounds and produce more enzymes to extract energy and nutrients from organic matter. Comparatively, Gram negative bacteria use labile C compounds and produce less enzymes (Fanin et al., 2018; Naylor and Coleman-Derr, 2018). Together these studies suggest the potential important contribution of the microbial community composition to ecosystem functioning (Graham et al., 2016) through its links with CWM biomass-specific activity. Finally, experimental results also provide some supports for a physiological acclimation of microbial community members or for an evolutionary adaptation of their population in response to environmental changes (Allison et al., 2014, 2018; Lashermes et al., 2016), affecting enzymes production independently of community composition or microbial biomass changes, potentially also contributing to variations of CWM biomass-specific activity.

To sum up, the control of potential extracellular enzyme activity in soil relies on four parameters: microbial biomass and three parameters potentially influencing biomass-specific activity: community composition, community members' acclimation/adaptation and enzyme abiotic stabilization (reduction of enzymes turnover by abiotic factors). To assess the relative importance of these four parameters, their physical control in a manipulated experiment would be very difficult and implicate a highly artificial environment. Structural equation model (SEM) framework can be used as an alternative to statistically assess the role of different mechanisms underlying observed responses in experimental or observational studies where factors affecting the processes under investigation cannot be physically controlled (Shipley, 2016).

Based on experimental data assessing ecosystem functioning across different management (conventional intensive vs. ecological intensive) and countries (France, Switzerland and Portugal) under 4 rain regime scenarios (Dry, Normal, Intermittent and Wet rain regimes, during 263 days, followed by 89 days of recovery), we used ecoenzymatic CWM traits (Piton et al., 2020): 1) to identify the links between traits and soil microbial community composition along abiotic gradients; and 2) to disentangle mechanisms driving the potential enzyme activity in soil.

\section{1) We hypothesized:}

A high biomass-specific activity (oligotrophic CWM trait), and a nutrient acquisition strategy to be associated with fungi and/or Gram positive dominated communities, explaining their dominance in low nutrients and low moisture conditions.

Then, we firstly assessed the relative importance of microbial biomass and biomass-specific activity in the variation of the total enzyme activity (ecosystem level property). Secondly, we used structural equation models to disentangle soil abiotic factors and microbial community composition control of microbial biomass and biomassspecific activity.

\section{2) We further hypothesized that:}

Microbial biomass variation is the main driver of the total enzyme activity in soil, and that altered rain regimes induce biomass-specific activity adjustment in response to resource availability changes. Biomass-specific activity is mainly controlled by changes in microbial community composition and to a lesser extent by community members' acclimation/adaptation or enzyme abiotic stabilization.

\section{Material and methods}

\subsection{Experimental design and setup}

In this study, we used data from a continental scale experiment testing effects of 4 rain regimes (normal, dry, wet and intermittent) on Terrestrial Model Ecosystems (TME) extracted from grasslands representing dominant pedoclimatic and management conditions across Europe (Table 1 and Lori et al. (2020) for details). One hundred and twenty TMEs ( $40 \mathrm{~cm}$ depth $\mathrm{x} 16.5 \mathrm{~cm}$ diameter) encased in HDTPE tubes were collected. More precisely, four different plots were sampled for each management (eco-intensive and conventional-intensive) in each country (8 plots per county), with 5 TMEs extracted in each plot, using a retroexcavator and a special stainless-steel extractor as described by Knacker et al. (2004).

After sampling, all TMEs were transported in a refrigerated truck to a single climate chamber at the Laboratory of Soil Ecology and Ecotoxicology of Coimbra University. TMEs were randomly placed inside special carts creating a temperature gradient between the lower and the upper part as described by $\mathrm{Ng}$ et al. (2014). Air humidity was maintained at $60 \%$ and temperature at $20{ }^{\circ} \mathrm{C}$ during the entire experiment and photoperiod was adjusted at $16 \mathrm{~h}: 8 \mathrm{~h}$ (light:dark).

During the first 81 days, artificial rainwater (Velthorst, 1993) was added on each TME, with the amount of water adjusted to obtain a soil 
Table 1

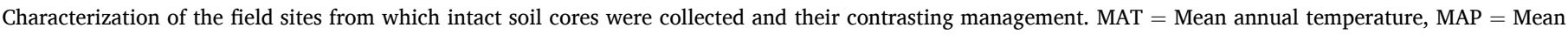
annual precipitation, $\mathrm{N}=$ Nitrogen. See Lori et al. (2020) for more details.

\begin{tabular}{|c|c|c|c|c|c|c|c|}
\hline $\begin{array}{l}\text { Country } \\
\text { (coordinates) }\end{array}$ & Land use & $\begin{array}{l}\text { N Fertilizer (average } \mathrm{N} \mathrm{kg} \mathrm{ha} \\
\text { year }^{-1} \text { ) }\end{array}$ & MAT, MAP & Texture & $\mathrm{pH}$ & SOM & WHCmax \\
\hline $\begin{array}{l}\text { Switzerland } \\
\qquad 47^{\circ} 30^{\prime} \mathrm{N} 7^{\circ} 33^{\prime} \mathrm{E}\end{array}$ & Grassland in rotation & $\begin{array}{l}\text { Ecological-intensive: Slurry (120) } \\
\text { Conventional-intensive: Synthetic } \\
(140)\end{array}$ & $9.7^{\circ} \mathrm{C}, 791 \mathrm{~mm}$ & Silt/Silt Loam & $\begin{array}{l}5.01 \\
( \pm 0.12)\end{array}$ & $\begin{array}{l}4.15 \% \\
( \pm 0.67)\end{array}$ & $58.91 \%(1.89)$ \\
\hline $\begin{array}{l}\text { France } \\
\qquad 45^{\circ} 07^{\prime} \mathrm{N} 5^{\circ} 31^{\prime} \mathrm{E}\end{array}$ & Mountain grassland & $\begin{array}{l}\text { Ecological-intensive: Cow manure } \\
\text { (30) } \\
\text { Conventional-intensive: Cow manure } \\
\text { (70) }\end{array}$ & $\begin{array}{l}7.2^{\circ} \mathrm{C}, 1483 \\
\mathrm{~mm}\end{array}$ & $\begin{array}{l}\text { Sandy Loam/ } \\
\text { Loam }\end{array}$ & $\begin{array}{l}5.71 \\
( \pm 0.86)\end{array}$ & $\begin{array}{l}9.34 \% \\
( \pm 2.46)\end{array}$ & $\begin{array}{l}90.92 \% \\
( \pm 8.93)\end{array}$ \\
\hline $\begin{array}{l}\text { Portugal } \\
\qquad 38^{\circ} 42^{\prime} \mathrm{N} 8^{\circ} 19^{\prime} \mathrm{W}\end{array}$ & $\begin{array}{l}\text { Grassland in } \\
\text { agroforest }\end{array}$ & $\begin{array}{l}\text { Ecological-intensive: None (0) } \\
\text { Conventional-intensive: Synthetic } \\
\text { (56) }\end{array}$ & $\begin{array}{l}16.5^{\circ} \mathrm{C}, 1093 \\
\mathrm{~mm}\end{array}$ & Sandy Loam & $\begin{array}{l}4.62 \\
( \pm 0.35)\end{array}$ & $\begin{array}{l}3.55 \% \\
( \pm 0.64)\end{array}$ & $\begin{array}{l}39.18 \% \\
( \pm 4.45)\end{array}$ \\
\hline
\end{tabular}

moisture in the upper $20 \mathrm{~cm}$ layer (assessed using Decagon moisture sensors) equivalent to $50 \%-60 \%$ of the maximum water holding capacity $\left(\mathrm{WHC}_{\max }\right)$ of the soil from each site where TMEs were collected. Those specific values of soil moisture $\left(50 \%-60 \% \mathrm{WHC}_{\max }\right)$ are considered as the "Normal" rain regime for each country. After this acclimation period under "Normal" rain regime, the upper $10 \mathrm{~cm}$ of soil were sampled on one TMEs (destructive sampling) to characterize initial state (T0).

After this acclimation period, 4 rain regimes were simulated during 263 days, with one rain regime simulated on each of the four TME left from the 32 plots. Soil moisture was maintained at $20-30 \%, 50 \%-60 \%$ and $70-80 \%$ of the WHCmax for Dry, Normal and Wet rain regimes respectively. Intermittent rain regime was also simulated with 74 days under wet rain regime followed by 125 days under dry regime and finally 64 days back to normal.

After this period (T1). One soil core of $98 \mathrm{~cm}^{3}(5 \mathrm{~cm}$ diameter and 5 $\mathrm{cm}$ height) was collected from each TME (non-destructive sampling) and pure sand encased into a small plastic cylinder was used to fill the holes left after sampling. After this period of altered rain regimes, all TMEs were set again to Normal rain regime for 89 days followed by a last destructive sampling (T2) as described for T0 (upper $10 \mathrm{~cm}$ ). At the 3 sampling times, soils were sieved at $5 \mathrm{~mm}$, plant roots were hand-sorted and samples were stored at $4{ }^{\circ} \mathrm{C}$ or $-20^{\circ} \mathrm{C}$ for further analyses.

\subsection{Soil abiotic properties}

Soil moisture was determined as the weight difference of a fresh soil sample after drying it for 1 week at $70{ }^{\circ} \mathrm{C}$, followed by $4 \mathrm{~h}$ at $500{ }^{\circ} \mathrm{C}$ to determine soil organic matter content (SOM) by loss on ignition. Soil $\mathrm{pH}$ was determined in a 1:6 (soil: $1 \mathrm{M} \mathrm{KCl}$ ) solution. Total soil $\mathrm{N}$ content was measured using an elemental analyzer (FlashEA 1112, Fisher Scientific, Waltham, Massachusetts, USA) on oven-dried subsamples ground to a fine powder ( $5 \mu \mathrm{m}$ diameter) with a ball mill (MM301, Retsch $\mathrm{GmbH}$, Haan, Germany).

\subsection{Microbial community biomass and composition}

Analysis of phospholipid fatty acids (PLFA) were used to characterize microbial biomass and community composition. Lipids were extracted from $3 \mathrm{~g}$ of soil according to Frostegård et al. (1993). Separation of the resulting fatty acid methyl esters was done on a Hewlett Packard 6890 gas chromatograph (column HP 5). PLFAs i15:0, a15:0, 15:0, i16:0,

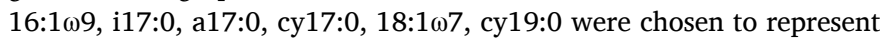
bacterial biomass. PLFA 18:2 $\omega 6$ was used as an indicator of fungal biomass (Frostegård and Bååth, 1996). Gram positive biomass was indicated by i15:0, a15:0, i16:0, i17:0, a17:0 (O'leary and Wilkinson,

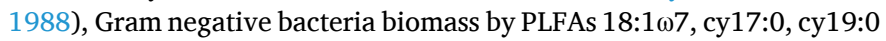
(Wilkinson, 1988; Zelles, 1997) and Actinobacteria biomass by 10Me17:0 and 10Me18:0 (Lechevalier and Moss, 1977; Kroppenstedt, 1985). The NLFA 16:1 105 was used as an indicator for AMF biomass
(Olsson et al., 1995). Microbial biomass-C was calculated based on the conversion factors: $363.6 \mathrm{nmol}$ of bacterial-PLFA $=1 \mathrm{mg}-\mathrm{C}$ (Frostegård and Bååth, 1996), $11.8 \mathrm{nmol}$ of fungal-PLFA = $1 \mathrm{mg}$-C (Klamer and Bååth, 2004) and $1.047 \mathrm{nmol}$ of NLFA = $1 \mu \mathrm{g}-\mathrm{C}$ (Olsson et al., 1995).

The Fungal:Bacterial ratio and Gram + :Gram- ratio were calculated as Fungal biomass-C: Bacterial biomass- $\mathrm{C}$ ratio ( $\mathrm{F}: \mathrm{B}$ here after), and Gram + biomass-C: Gram- biomass-C ratio (GP:GN hereafter) respectively. Relative abundances (\% mol PLFA) of 27 identified PLFA markers were used to characterize the overall microbial community composition.

\subsection{Potential extracellular enzyme activities}

Standard fluorimetric methods were used to measure potential extracellular enzymes activity of seven enzymes degrading C-rich substrates ( $\alpha$-Glucosidase (AG), $\beta$-1,4-Glucosidase (BG), $\beta$-D-Cellobiosidase (CB), and $\beta$-Xylosidase (XYL)), N-rich substrates ( $\beta$-1,4-N-acetylglucosaminidase (NAG) and leucine aminopeptidase(LAP)) and P-rich substrates (phosphomonoesterase (PHOS)) (Bell et al., 2013). Briefly, $2.75 \mathrm{~g}$ of frozen soil was thawed at room temperature and directly homogenized ( $1 \mathrm{~min}$ in a Waring blender) in $200 \mathrm{ml}$ of a sodium acetate buffer solution adjusted to the mean soil $\mathrm{pH}(5.1 \pm 0.7 \mathrm{SD}, \mathrm{N}=24)$ measured at $\mathrm{T}_{0}$. The soil slurry $(800 \mu \mathrm{L})$ was then added in technical duplicates to a 96-deep-well microplate with $200 \mu \mathrm{L}$ of substrates at saturation concentration $\left(\mathrm{V}_{\max }\right)$. For each soil sample, duplicated standard curves $(0-100 \mu \mathrm{M}$ concentration) were prepared by mixing $800 \mu \mathrm{L}$ of soil slurry with $200 \mu \mathrm{L}$ of 4-methylumbelliferone (MUB) or 7-amino-4-methylcoumarin (MUC) in 96-deep-well microplates. Plates were incubated at 20 ${ }^{\circ} \mathrm{C}$ in the dark $(3 \mathrm{~h})$ on a rotary shaker $(150 \mathrm{rpm})$ before centrifugation at $2900 \mathrm{~g}(3 \mathrm{~min})$. The supernatant $(250 \mu \mathrm{L})$ was transferred to a black Greiner flat-bottomed plate and fluorescence was measured on a microplate reader (Varioscan Flash, Thermo Scientific) with excitation wavelength set to $365 \mathrm{~nm}$ and emission set to $450 \mathrm{~nm}$. After correcting for negative controls, potential enzyme activities were expressed as nmol $\mathrm{g} \mathrm{soil}^{-1} \mathrm{~h}^{-1}$. Then, enzymes activities have been summed to represent enzyme activity degrading C-rich (EEC $=\mathrm{AG}+\mathrm{BG}+\mathrm{CB}+$ $\mathrm{XYL}), \mathrm{N}$ rich $(\mathrm{EEN}=\mathrm{LAP}+\mathrm{NAG}), \mathrm{P}$ rich substrates $(\mathrm{EEP}=\mathrm{PHOS})$ and total enzymes activity (EEA $=\mathrm{EEC}+\mathrm{EEN}+\mathrm{EEP})$.

In this study, biomass-specific activity and ecoenzymatic stoichiometry were calculated and used as ecoenzymatic CWM traits proxies (Piton et al., 2020). Biomass-specific activity was obtained by weighting total enzyme activity with microbial biomass-C. This indicator has been considered as a proxy of the average investment in extracellular enzyme activity of one mass-unit of microbe (Allison et al., 2007b; Moorhead et al., 2013; Malik et al., 2019b). Eco-enzymatic stoichiometry was obtained following Sinsabaugh et al. (2009).

Enzymatic C:N ratio (EEC:EEN) $=\ln (\mathrm{BG}): \ln (\mathrm{NAG}+\mathrm{LAP})$,

Enzymatic C:P ratio (EEC:EEP) $=\ln (\mathrm{BG}): \ln (\mathrm{PHOS})$

Enzymatic N:P ratio (EEN:EEP) $=\ln (\mathrm{NAG}+\mathrm{LAP}): \ln (\mathrm{PHOS})$. 
These ratios were assumed to indicate the direction of the resource acquisition strategy (toward $\mathrm{C}, \mathrm{N}$ or $\mathrm{P}$ ).

\subsection{Statistical approach}

\subsubsection{Microbial community composition}

A Principal Coordinates Analysis (PCoA) was conducted on the relative abundances of the 27 individual PLFAs at T0, T1 and T2 (full dataset). Then, sample coordinates from the first axis of this PCoA were used as a synthetic variable representing the overall variation in $\mathrm{mi}$ crobial community composition.

\subsubsection{Correlations between soil abiotic properties, microbial community composition and ecoenzymatic CWM traits}

Effects of sampling time, microbial community composition (F:B, GP: GN, PCoA-1), soil abiotic properties (Soil-N, pH and moisture) and their interactions on ecoenzymatic stoichiometry (EEC:EEN, EEC:EEP and EEN:EEP) were assessed using mixed effect models with country and plot nested in country as random factors. We also assessed correlations between microbial composition and soil abiotic properties (Soil-N, pH, moisture) for each sampling time (T0, T1, T2) using mixed effect correlations.

\subsubsection{Factor controlling microbial biomass and total enzyme activity}

The natural logarithm of the total soil enzyme activity (EEA) can be decomposed in the sum of the natural logarithm of biomass-specific activity $\left(\ln \left(\frac{\text { EEA }}{\text { Biomass }}\right)\right)$, and natural logarithm of biomass $(\ln ($ Biomass $))$.

$\ln ($ EEA $)=\ln \left(\frac{\text { EEA }}{\text { Biomass }} \times\right.$ Biomass $)$

$\ln (\mathrm{EEA})=\ln \left(\frac{\mathrm{EEA}}{\text { Biomass }}\right)+\ln ($ Biomass $)$

To assess the relative importance of these 2 components (biomassspecific activity and biomass) in the control of total enzyme activity, regressions of $\ln (\mathrm{EEA})$ on $\ln$ (Biomass) were fitted for each sampling time. Assuming soil microbial biomass to be the first parameter controlling total enzyme activity, the proportion explained by the model represents the importance of biomass in the control of total enzyme activity in soil while the non-explained variation was attributed to variation in biomass-specific activity.

Piecewise structural equation models (SEM) were used to assess the most important mechanisms driving both parameters (biomass and biomass-specific activity, Fig. 2). This method is less sensitive to sample size than standard SEM and enables to implement mixed effect model in the SEM structure (Lefcheck, 2016). In such approach, Shipley's test of directed separation (based on a chi-square test (see (Shipley, 2000, 2009))) is used to assess model goodness-of-fit, testing if missing paths exist in the model structure. When several models are accepted, information criterion such as Akaike information criterion or Bayesian Information Criterion (BIC) can be used to identify the best model. To obtain the most parsimonious model we used a three steps selection process, testing a series of potential mechanisms through which soil abiotic environment might influence extracellular enzyme activity, established based on our knowledge of the system (Laughlin et al., 2007; Grace et al., 2015). Firstly, a SEM was fitted with the most parsimonious a priori structure, stating that biomass-specific activity was only driven by community composition (Fig. 2), and then model fit was assessed. In the case of model rejection ( $\mathrm{p}$-val $<0.05$ ), potential missing paths in the SEM structure (such as direct effect of soil abiotic properties on biomass-specific activity, indicating community member's acclimatio$\mathrm{n}$ /adaptation enzyme abiotic stabilization) were evaluated using d-sep test (Shipley, 2000, 2003). Secondly, missing paths were added and model fit was newly assessed. Finally, we used a stepwise removal process of non-significant relationships. As De Vries and Bardgett (2016), we tested the effect of each removal using Bayesian Information

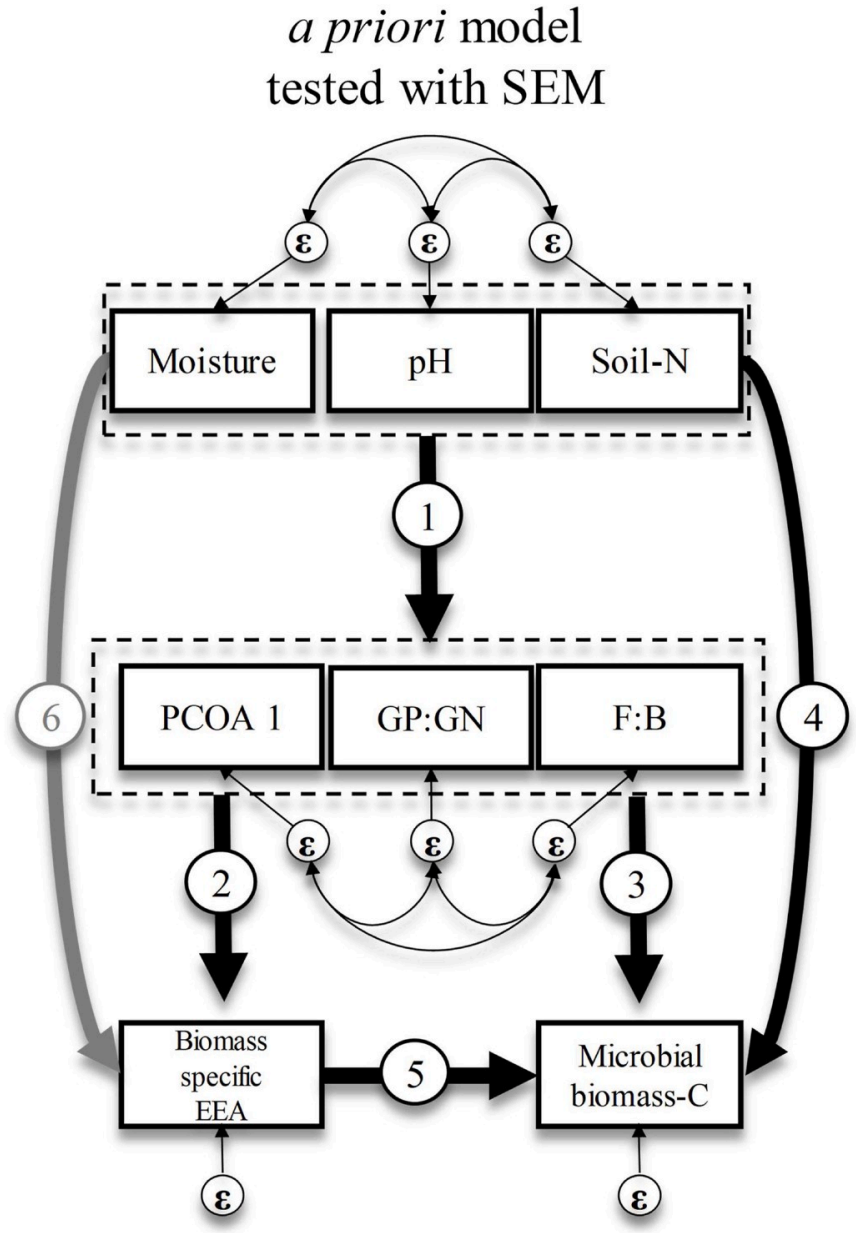

Fig. 2. A priori model tested using piecewise-SEM stating: soil abiotic factors influence on microbial community composition (arrow 1) and community composition effect on biomass-specific activity (arrow 2) explained by the difference in enzyme production between taxa; community composition effect on biomass-C (arrow 3) explained by stoichiometry, growth or carbon use efficiency difference between taxa; direct abiotic effect of soil abiotic properties which influence amount and availability of resources (arrow 4); potential cost of enzyme production for biomass-C build up (arrow 5); direct effect of soil abiotic properties on biomass-specific activity (arrow 6) representing either a community members' acclimation/evolution (change in enzyme production without modification of community composition) or enzyme abiotic stabilization (reduction of enzyme turnover in soil induced by change in abiotic environment). Arrow 6 (grey) was initially not included in the model and only added according to d-sep test (Shipley, 2000, 2003; Lefcheck, 2016). $\varepsilon$ represent error terms. One-headed arrows represent causal relationships; double-headed arrows represent free correlations.

Criterion (BIC). BIC was used instead of Akaike information criterion because BIC better identified true model in a simulation study with conditions close to our experiment (Hertzog, 2018). Each removal was retained if it did not induce a significant increase of BIC criteria (delta BIC $<2$ ) compared to the model with the lower BIC. Global model fit and quality of the final model was verified using Fisher's $C$ test, $R^{2}$ of endogenous variables and path significances before starting interpretation, as suggested by Hertzog (2018). Analyses were run under R.3.5.152 (Development Core Team, 2013). using packages piecewiseSEM for SEMs (Lefcheck, 2016), nlme for mixed effect models (Pinheiro et al., 2017), and ape for PCoA (Paradis and Schliep, 2019). 


\section{Results}

\subsection{Influence of soil abiotic properties on microbial community} composition

A large proportion (43\%) of the microbial community composition was explained by the first axis of the PCoA (PCoA-1, Fig. 3). PLFAs contributing the most to this axis (coordinates higher than 0.1 or lower

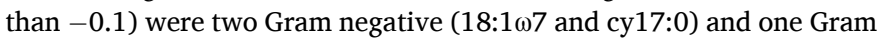
positive (a15:0) bacteria which were negatively related to the PCoA-1, whereas two Gram positive (i15:0 and i17:0), one from Actinobacteria (10Me17:0) and one from unclassified bacteria (15:0) were positively associated (Fig. 3).

The F:B ratio decreased in nutrient rich, alkaline soils under wet condition, as demonstrated by a negative association with soil-N (T0, $\mathrm{T} 2), \mathrm{pH}(\mathrm{T} 0, \mathrm{~T} 2)$ and moisture (T0, T1, T2) (Table 2). The GP:GN ratio also decreased with nutrient availability (i.e. soil-N at T1 and T2), and alkalinity (i.e. pH at T1, and T2). PCoA-1 (Fig. 3) showed almost the same behaviour, with negative association with $\mathrm{pH}$ (T0, T1, T2), soil-N (T0, T1) and moisture (T0) (Table 2).

\subsection{Influence of soil abiotic properties and microbial community composition on ecoenzymatic stoichiometry}

The association between ecoenzymatic EEC:EEN and EEC:EEP and soil abiotic properties highly varied between sampling times (significant interaction between soil properties and time, Fig. 4). Negative association between soil-N and EEC:EEN was observed only at T0, whereas EEC: EEN showed a negative association with $\mathrm{pH}$ at $\mathrm{T} 0$, shifting to positive at $\mathrm{T} 2$, and a negative association with moisture at $\mathrm{T} 0$ shifting to a positive association at T1 and T2. EEC:EEP ratios showed positive association with soil $\mathrm{pH}$ (T1 and T2) and moisture (T2). EEN:EEP showed more constant relationships with soil abiotic properties, increasing with soil-N and $\mathrm{pH}$ and decreasing with soil moisture at all sampling times (Fig. 4).

Conversely, associations between microbial community composition and ecoenzymatic stoichiometry were highly constant between sampling times (Fig. 5). More fungal dominated communities (i.e. high F:B)

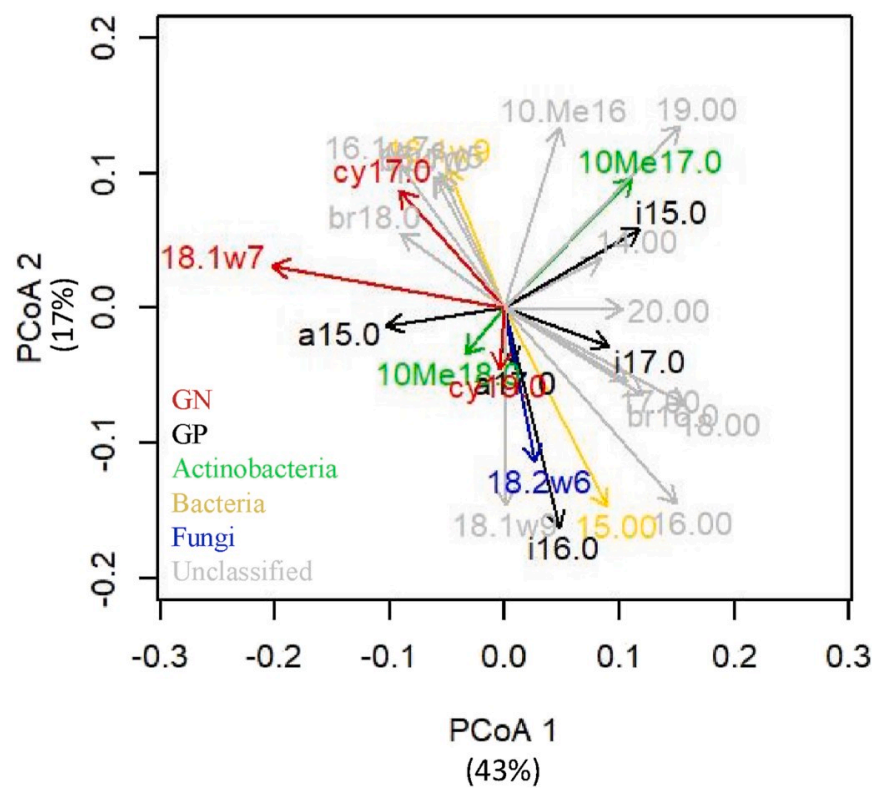

Fig. 3. PCoA plot of the 27 identified PLFAs from the 3 sampling times (T0, T1 and T2) representing the overall variation of the microbial community composition. Colours represent microbial groups. (For interpretation of the references to colour in this figure legend, the reader is referred to the Web version of this article.) showed an $\mathrm{N}$ acquisition strategy as demonstrated by a positive correlation of F:B with EEN:EEP and a negative one with EEC:EEN (Fig. 5). The GP:GN ratio shifted toward a more P-oriented strategy with increasing Gram positive abundance, and toward $\mathrm{C}$ and $\mathrm{N}$ oriented strategy for Gram negative bacteria as demonstrated by negative associations of GP:GN with EEC:EEP and EEN:EEP (Fig. 5). Correlations between GP:GN and EEC:EEN and between F:B and EEC:EEP were not significant. PCoA-1 showed the same association with ecoenzymatic stoichiometry than the GP:GN ratio (data not shown).

\subsection{Contributions of microbial biomass and biomass-specific activity to total enzyme activity}

The total enzyme activity was significantly correlated with microbial biomass at all sampling times ( $\mathrm{p}<0.001$ ), with $\mathrm{R}^{2}$ varying from $91 \%$ of the EEA variation explained by biomass at $\mathrm{T} 0$, to $46 \%$ at $\mathrm{T} 1$ and $62 \%$ at $\mathrm{T} 2$, indicating a higher contribution of microbial biomass to potential soil enzyme activity before altered rain regime simulation (T0) and after the recovery period (T2), whereas biomass-specific activity was the most the dominant factor explaining potential soil enzyme activity at the end of the altered rain regime period (T1) (Fig. 6).

\subsection{Drivers of microbial biomass and biomass-specific activity}

Due to their high covariation, PCoA-1 and GP:GN ratio $\left(\mathrm{R}^{2}=0.42\right.$, $\mathrm{p}$ $<0.001$ ), showed similar responses to soil abiotic factors and had the same effect on biomass-specific activity and microbial biomass. PCoA-1 better explained biomass-specific activity and was therefore conserved in the final structural equation model (Fig. 7). At T0 the SEM with full $a$ priori structure stating that biomass-specific activity was only driven by microbial community composition, and not by community members' acclimation/adaptation and enzyme stabilization, was accepted (C6 = $6.05, p=0.42$, BIC $=88.68$ ). Then model simplification based on BIC criterion led to the removal of 6 paths (Fig. $7, \mathrm{C} 18=10.31, \mathrm{p}=0.92$, $\mathrm{BIC}=77.05$ ). At T1 the SEM with full a priori structure was rejected (C6 $=18.34, \mathrm{p}=0.005, \mathrm{BIC}=136.47$ ) indicating missing paths in the SEM structure: Community composition was not sufficient to explain biomass-specific activity, suggesting community members' acclimation/ adaptation and/or enzyme abiotic stabilization also occurred. D-sep tests showed a missing path between biomass-specific activity and moisture. The addition of this path improved the SEM which was finally accepted ( $\mathrm{C} 4=2.838, \mathrm{p}=0.59$, BIC $=125.51)$, then model simplification led to the removal of 2 paths (Fig. $7, \mathrm{C} 8=11.17, \mathrm{p}=0.19$, BIC $=$ $124.75)$. At $\mathrm{T} 2$ the $a$ priori model was accepted (C6 $=7.89, \mathrm{p}=0.25$, BIC $=126.56$ ), and model simplification based on BIC criterion led to the removal of 4 paths (Fig. 7, C14 $=15.75, \mathrm{p}=0.33$, BIC $=116.17$ ).

\section{Discussion}

\subsection{Ecoenzymatic CWM traits are tightly linked with microbial community composition along abiotic gradients}

Variations of microbial community composition along environmental gradients have been extensively reported (Fierer and Jackson, 2006; Allison et al., 2007b; Lauber et al., 2009; De Vries et al., 2012; Fierer et al., 2012a; Ren et al., 2018; Martinez-Almoyna et al., 2019). However, these studies rarely explored how the observed community shifts could explain microbial trait variations (Fierer et al., 2012b; Leff et al., 2015). Community weighted mean (CWM) trait values (the average trait value per unit of biomass within a community) is mostly driven by traits of the dominant species (Lavorel and Garnier, 2002; Garnier et al., 2004). Thus, these CWM traits are expected to be associated with the adaptive value of traits along environmental gradients that control community composition changes (Ackerly, 2003; Shipley et al., 2006; Laughlin et al., 2018). The first aim of this study was to assess the relationships between microbial community composition and 
Table 2

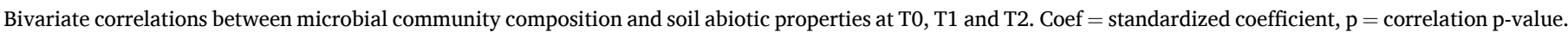
Values in bold indicate a significant p-value.

\begin{tabular}{|c|c|c|c|c|c|c|c|}
\hline \multirow[t]{3}{*}{ Microbial community composition } & \multirow[t]{3}{*}{ Time } & \multicolumn{6}{|c|}{ Soil abiotic properties } \\
\hline & & \multicolumn{2}{|l|}{ Soil-N } & \multicolumn{2}{|l|}{$\mathrm{pH}$} & \multicolumn{2}{|c|}{ Moisture } \\
\hline & & Coef & $\mathrm{p}$ & Coef & $\mathrm{p}$ & Coef & $\mathrm{p}$ \\
\hline \multirow[t]{3}{*}{$\mathrm{F}: \mathrm{B}$} & T0 & -0.62 & $<0.01$ & -0.40 & 0.05 & -0.68 & $<0.01$ \\
\hline & $\mathrm{T} 1$ & -0.21 & 0.08 & -0.17 & 0.13 & -0.25 & 0.01 \\
\hline & $\mathrm{T} 2$ & -0.28 & 0.02 & -0.33 & $<0.01$ & -0.36 & $<0.001$ \\
\hline \multirow[t]{3}{*}{ GP:GN } & T0 & -0.18 & 0.17 & -0.14 & 0.22 & -0.54 & 0.01 \\
\hline & $\mathrm{T} 1$ & -0.41 & $<0.001$ & -0.26 & $<0.01$ & -0.20 & 0.03 \\
\hline & $\mathrm{T} 2$ & -0.22 & 0.03 & -0.24 & $<0.001$ & -0.21 & 0.05 \\
\hline \multirow[t]{3}{*}{ PCoA-1 } & T0 & -0.26 & $<0.01$ & -0.18 & 0.03 & -0.57 & $<0.001$ \\
\hline & $\mathrm{T} 1$ & -0.40 & $<0.001$ & -0.43 & $<0.001$ & 0.09 & 0.30 \\
\hline & $\mathrm{T} 2$ & -0.12 & 0.14 & -0.39 & $<0.001$ & -0.02 & 0.83 \\
\hline
\end{tabular}

\section{T0 T1 T2}
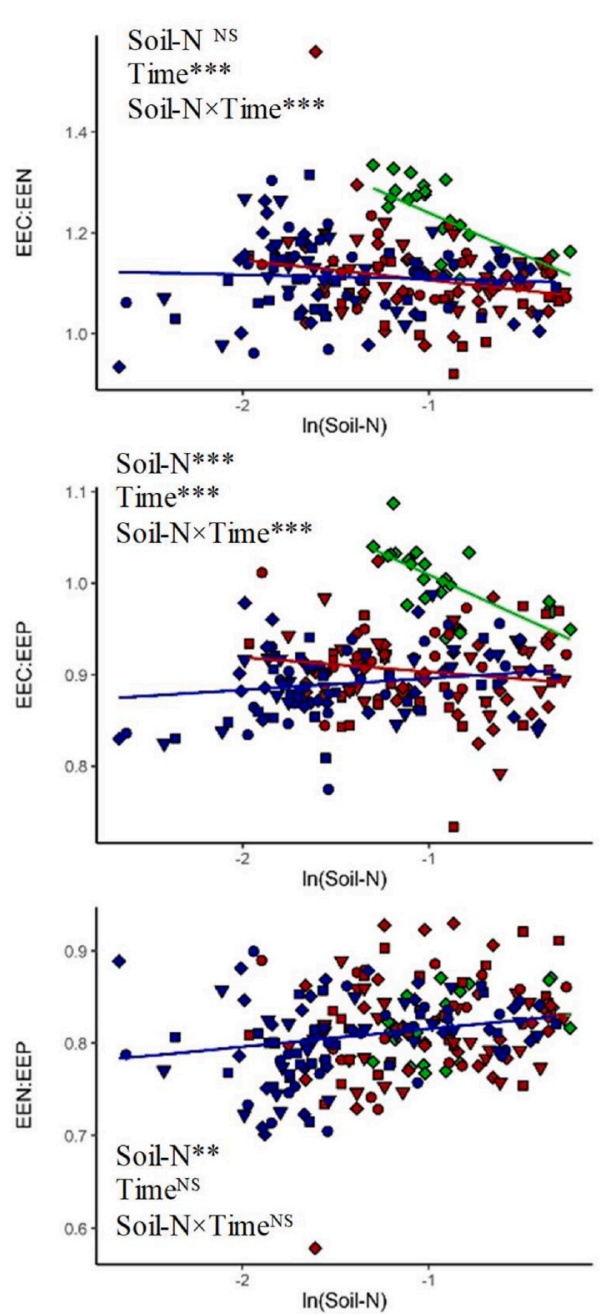
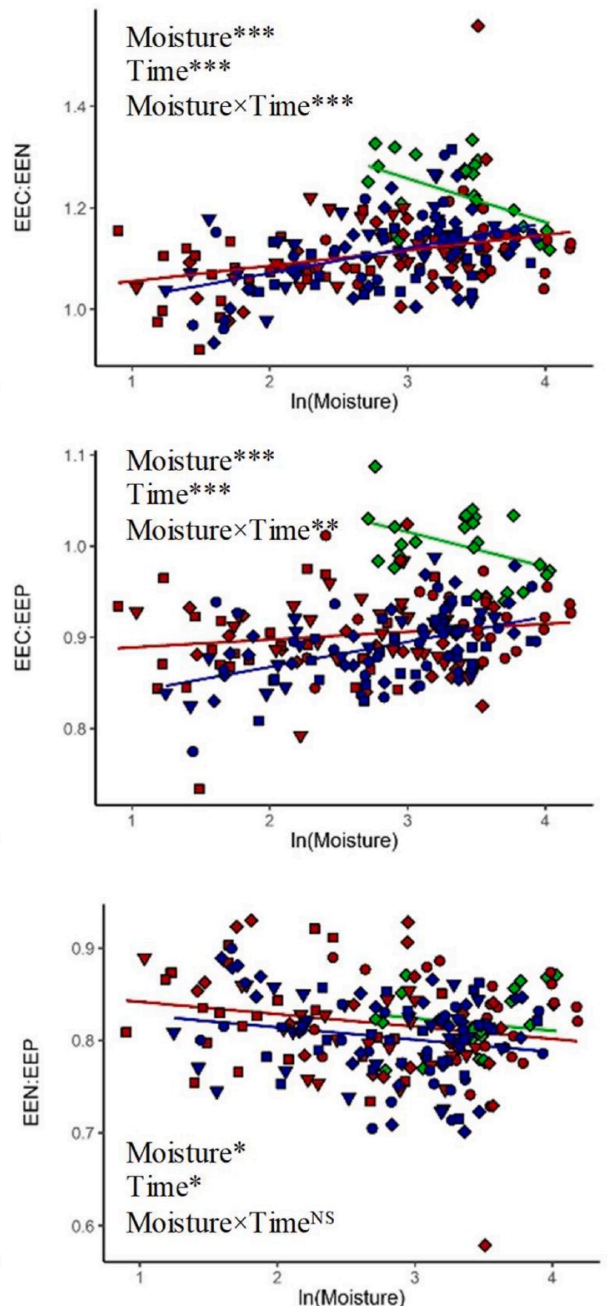

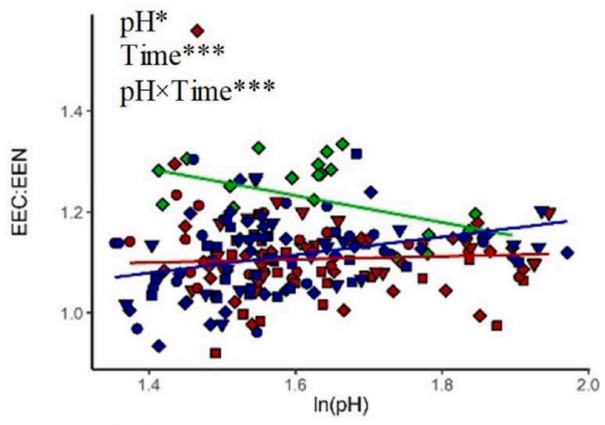

$\mathrm{pH}^{* * * *}$
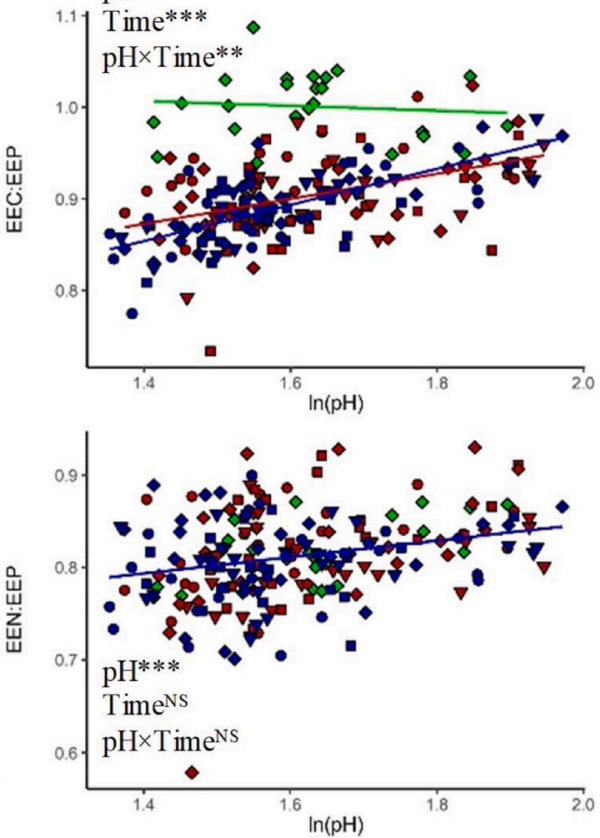

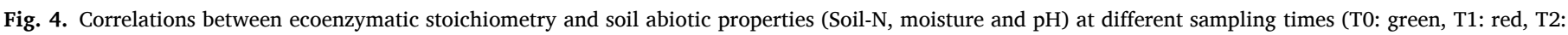

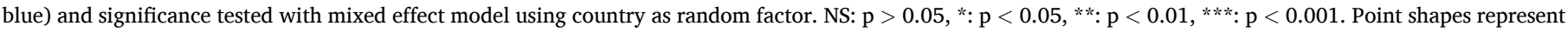

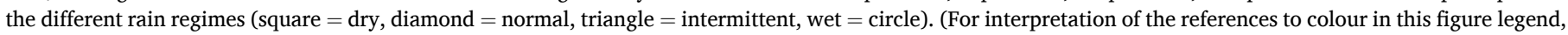
the reader is referred to the Web version of this article.)

ecoenzymatic CWM traits proxies (Piton et al., 2020) along environmental gradients.

Observed associations between soil abiotic properties and community composition were consistent with the literature (De Vries et al., 2006; Ho et al., 2017; Naylor and Coleman-Derr, 2018), indicating that oligotrophic environments (low resource availability) favour fungi 
T0 T1 T2
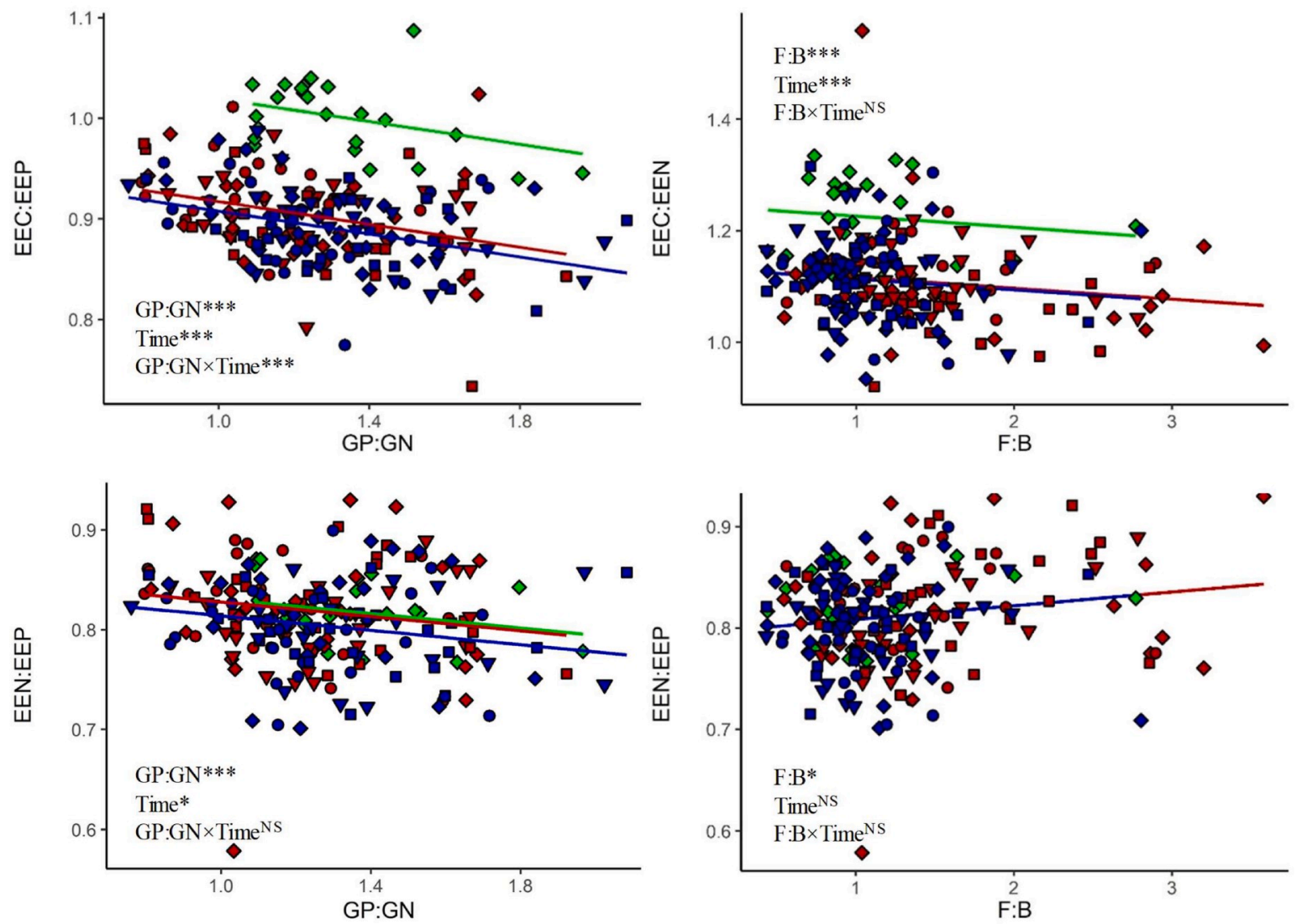

Fig. 5. Correlation between ecoenzymatic stoichiometry and community composition (Gram positive: Gram negative (GP:GN) and Fungal: Bacterial (F:B) ratios) at different sampling time (T0: green, T1: red, T2: blue) and significance tested using mixed effect model using country as random factor. Correlations between GP:GN and EEC:EEN and between F:B and EEC:EEP are not presented because they were not significant. NS: $p>0.05,{ }^{*}: \mathrm{p}<0.05$, ${ }^{* *}: \mathrm{p}<0.01$, ${ }^{* * *}: \mathrm{p}<0.001$. Point shapes represent the different rain regimes (square $=$ dry, diamond $=$ normal, triangle $=$ intermittent, wet $=$ circle). (For interpretation of the references to colour in this figure legend, the reader is referred to the Web version of this article.)

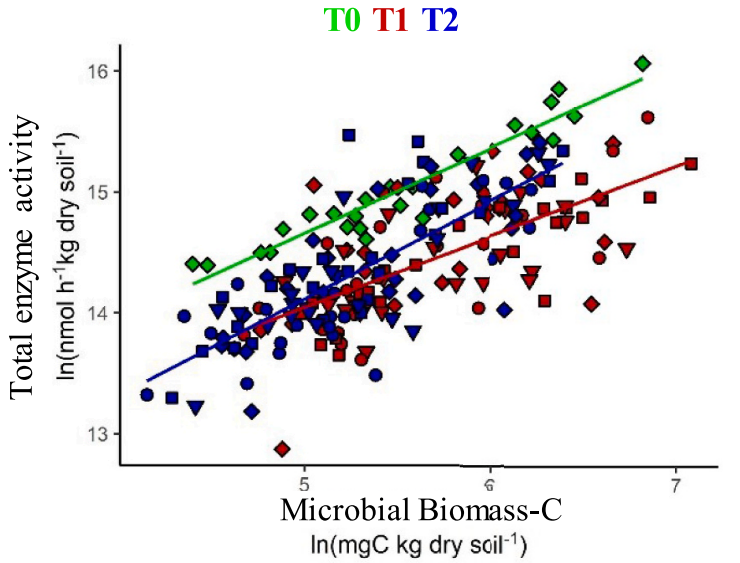

and Gram positive bacteria, while resource-rich conditions were beneficial for Gram negative bacteria (Fig. 7 and Table 2). Our trait-based approach showed distinct ecoenzymatic CWM traits associated with these three microbial groups potentially explaining their dominance in oligotrophic and copiotrophic environments respectively. First, fungi were associated with lower biomass-specific activity and their ecoenzymatic stoichiometry suggested their enzyme production to be oriented preferentially toward $\mathrm{N}$ acquisition (Fig. 5). Second, Gram positive
Explained by :

Biomass-specific activity

Biomass-C

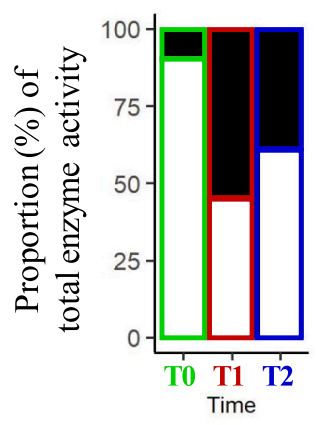

Fig. 6. Correlation between the natural logarithm of the total enzyme activity and the natural logarithm of microbial biomass-C for the three sampling times (T0: green points solid line, T1: red points, dotted line T2: blue points dashed line), left panel. Proportion of total enzyme activity explained by biomass-C $\left(R^{2}\right.$ of the correlation between natural logarithm of the enzyme activity and the natural logarithm of microbial biomass) and biomass-specific activity (variation not explained by biomass-C), right panel. (For interpretation of the references to colour in this figure legend, the reader is referred to the Web version of this article.) bacteria were associated with a higher investment in extracellular enzymes production oriented toward P acquisition (Fig. 5). Finally, Gram negative bacteria showed lower investment in enzyme production and a strategy oriented toward $\mathrm{C}$ acquisition. The lower biomass-specific potential enzyme activity in more fungal dominated communities (Fig. 7) was unexpected since fungi are commonly considered as principal enzyme producers in soils (Sinsabaugh, 2005; Romani et al., 2006). However, only hydrolytic enzymes were measured in this study and not 
Before stress (TV)

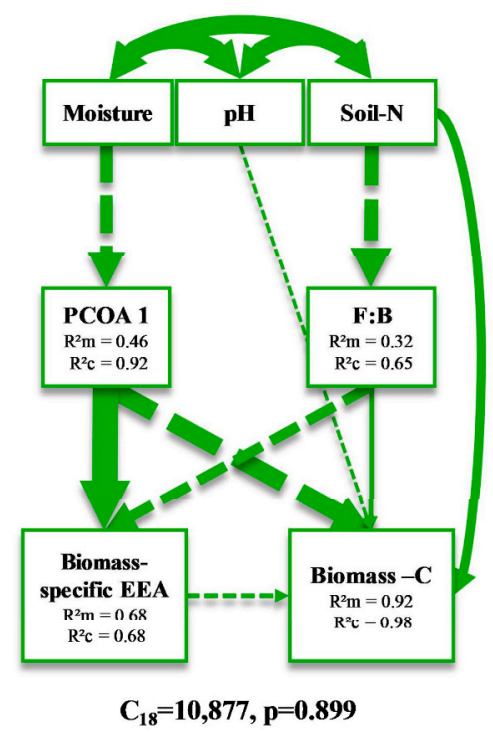

End of stress period

(T1)

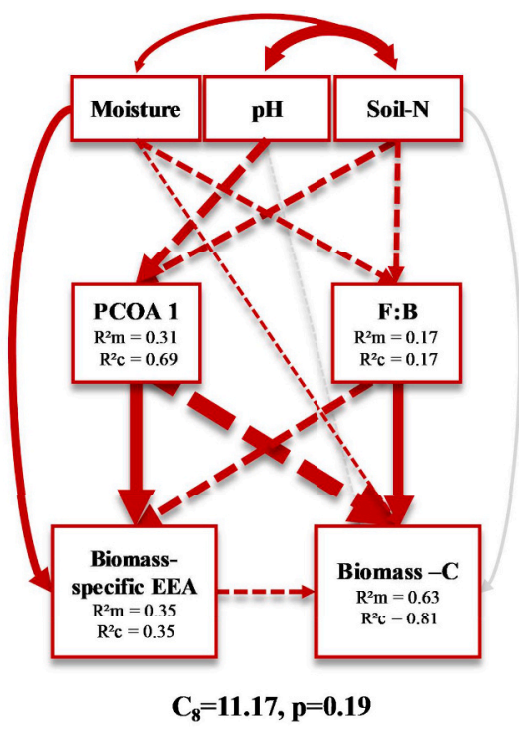

End of recovery period

(T2)

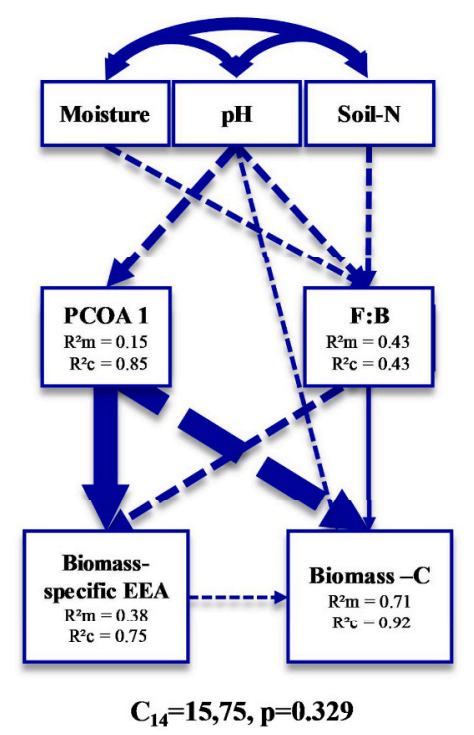

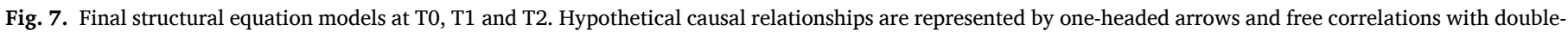

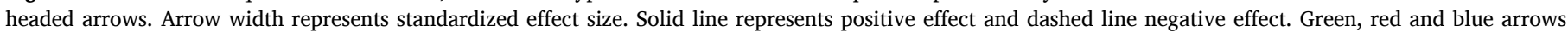
represent significant effect and grey arrows non-significant effect conserved during selection process.

oxidative ones, which could have biased this observation. Oxidative enzyme production has being observed in both bacterial and fungal groups (Allison et al., 2007a), but the capacity to produce enzymes degrading lignin is more restricted in microbes than hydrolase production, with important contributions attributed to fungi such as white-rot basidiomycetes (Kirk and Farrell, 1987; Boer et al., 2005). Thus, the pattern observed here might also correspond to a shift from a resource acquisition strategy based on hydrolytic enzymes from bacteria, to a strategy more based on oxidative enzymes from fungi. Similar work, crossing hydrolase and oxidase measurements, should shed light on such potential trade-off. Overall, this result was consistent with the growing idea that bacteria are also important in organic matter degradation (López-Mondéjar et al., 2019). Furthermore, fungal dominance in $\mathrm{N}$-poor soil observed at $\mathrm{T} 0$ and $\mathrm{T} 2$ (Table 2), associated with higher relative production of $\mathrm{N}$-acquisition enzyme (Fig. 5), supports the resource allocation model, which predicts higher investment in $\mathrm{N}$ acquisition when $\mathrm{N}$ is limiting (Sinsabaugh et al., 1993). Considering also the higher biomass $\mathrm{C}: \mathrm{N}$ ratio of fungi compared to bacteria (Strickland and Rousk, 2010), higher biomass C:N combined with lower EEC:EEN ratio seems to be two response traits associated to low $\mathrm{N}$ and high C availability (Mooshammer et al., 2014), likely explaining fungal dominance in such environments. However, direct measurement of microbial biomass stoichiometry would be necessary to fully validate this mechanism.

Decreases of GP:GN and PCoA-1 were associated with variations in ecoenzymatic stoichiometry indicating a shift from $P$ to $C$ acquisition concomitant to a reduction of biomass-specific activity, consistent with our hypothesis 1 . The most constant abiotic driver of GP:GN and ecoenzymatic C:P ratio was $\mathrm{pH}$. $\mathrm{pH}$ is known to strongly influence $\mathrm{P}$ availability, potentially explaining why microbes invest more in $\mathrm{P}$ acquisition in acidic soil and shift for $\mathrm{C}$ acquisition under neutral conditions where $\mathrm{pH}$ constraint on $\mathrm{P}$ availability is released ( $\mathrm{Xu}$ et al., 2017). Our results are also consistent with Gram positive bacteria having a more oligotrophic strategy (Naylor and Coleman-Derr, 2018), and depict two traits that might explain their dominance in resource poor and acidic soils: a higher investment in extracellular enzymes to cope with low resource availability (Fontaine et al., 2003; Allison et al., 2007b; Malik et al., 2019b), and a preferential investment in P acquisition to cope with low P availability. Contrastingly, Gram negative bacteria showed a copiotrophic strategy, producing less enzymes (Fontaine et al., 2003), and relying on labile C from plants (Fanin et al., 2018), two traits that might explain their dominance in neutral and resource rich soils. Adding molecular characterization of the microbial communities to our approach would be very valuable to further identify CWM traits associated with community composition at different taxonomic resolution.

Ecoenzymatic EEC:EEN ratio was related to soil $\mathrm{N}$ at T0, and became more associated to soil moisture at $\mathrm{T} 1$ and $\mathrm{T} 2$ (Fig. 4), while remaining strongly negatively associated with F:B at all sampling times (Fig. 5). The relationship between ecoenzymatic EEC:EEP and GP:GN ratio was also more stable through the experiment than the relationship between ecoenzymatic EEC:EEP ratio and soil abiotic factors. This suggests that ecoenzymatic stoichiometry was tightly associated with community composition. Thus, the predicted links between ecoenzymatic stoichiometry with C and nutrient availability (Sinsabaugh et al., 1993, 2009) might be limited if other factors such as soil moisture modify community composition.

\subsection{Total enzyme activity in soils: disentangling mechanisms}

The second aim of this study was to assess the relative importance of different mechanisms to control total potential enzyme activity in soils. Our results confirm our hypothesis that biomass primarily controlled total soil enzyme activity under stable conditions, whereas biomassspecific activity (a CWM trait) became the most important factor to predict variations under altered rain regimes (Fig. 6). This shows the need for a better understanding of the factors controlling microbial CWM trait variation to model and predict ecosystem level processes, and, especially their transient response to climate changes. Then, we used SEM to disentangle the predominant mechanisms controlling the variation in microbial biomass and biomass-specific activity.

\subsubsection{Factors controlling microbial biomass}

Microbial biomass was directly affected by soil-N at T0 (Fig. 7). 
Associated with soil organic matter quantity, higher soil $\mathrm{N}$ represents higher amount of resources available for microbes to build up biomass. We also found an important effect through community composition with F:B ratio having a positive effect on microbial biomass-C (Fig. 7), which might be explained by a higher fungal biomass C:N (Strickland and Rousk, 2010), a lower nutrient demand or a higher carbon use efficiency (Hodge et al., 2000; Keiblinger et al., 2010; Zechmeister-Boltenstern et al., 2015), indicating a higher capacity to build up microbial biomass-C for a same amount of resources. Conversely, PCoA-1, was negatively related to microbial biomass-C. This link with PCoA-1 was probably not due to a difference in biomass stoichiometry, as PCoA-1 was not associated with F:B ratio. However, oligotrophic communities as indicated by PCoA-1 were likely characterized by a lower investment in biomass production (Fig. 1) (Malik et al., 2019a, 2019c). The positive effect of bacterial community composition on biomass-specific activity, translating into a negative effect on biomass suggests that oligotrophic communities invest relatively more $\mathrm{C}$ in non-growth products such as enzymes (Malik et al., 2019a). Such trade-off (Fig. 1) needs further investigations using molecular and culturing approaches (Malik et al., 2019c; Ramin and Allison, 2019). Even if such trade-off across microbial diversity could justify to interpret these SEM paths accordingly (community composition affecting biomass-C), we acknowledge that a feedback might exist between community composition and biomass-C, with high biomass-C potentially influencing community composition by favouring competitive microbes. Thus, our SEM structure should be considered as a potential causal model rather than a proof of a unique causality. To sum up, these results might depict two parallel mechanisms influencing microbial biomass- $C$ through modifications in community composition: 1) a positive effect of fungal abundance through microbial biomass stoichiometry; 2) a negative effect of oligotrophic bacterial community through a higher investment in non-growth products. While the importance of $\mathrm{C}$ from microbial origin in soil organic $\mathrm{C}$ sequestration is increasingly recognized (Schmidt et al., 2011; Liang et al., 2017), our results provide insights on two potential microbial mechanisms controlling soil C sequestration (Trivedi et al., 2013).

\subsubsection{Factors controlling biomass-specific activity}

Studies isolating bacteria and fungi have reported differences in enzymatic traits among microbial taxa (e.g. Lladó et al., 2016; Pierre-Emmanuel et al., 2016), supporting the possibility of a community composition effect on enzyme activity in soils. However, in empirical studies directly measuring potential enzyme activity in soil, the effect of community composition on enzyme activity has rarely been assessed after correction for the microbial biomass effect (Kivlin et al., 2013). Using biomass-specific activity to correct for the biomass effects, our results gave support to this mechanism. Indeed, microbial community composition was the first driver of variation in biomass-specific activity (Fig. 7), which showed strong association with F:B, GP:GN and the first PCoA axis used as a proxy of variation in the overall community composition. It is interesting to note that PCoA-1 was a better predictor than a copiotrophic:oligotrophic indicator such as the GP:GN ratio for biomass-specific activity. This invites for further investigations of enzymatic trait variations at a lower taxonomic resolution than broad groups such as fungi, Gram positive and Gram negative bacteria (Ho et al., 2017).

Direct positive effects of soil moisture on biomass-specific activity were detected at $\mathrm{T} 1$, suggesting other mechanisms than microbial biomass and community composition to control enzyme activity. This direct effect can be attributed to modification of biomass-specific activity without change in community composition induced by physiological acclimation of microbes, and/or evolutionary adaptation of their populations (Schimel et al., 2007; Allison et al., 2014, 2018; Lashermes et al., 2016), and/or enzyme stabilization (Nannipieri et al., 2018). Our statistical approach does not enable us to decouple these mechanisms. However, enzyme turn-over is expected to be down regulated by soil drought, thus increasing the enzyme pool in soil (Steinweg et al., 2012;
Kivlin et al., 2013), though we observed a negative effect of dry conditions. Consequently, we attributed the positive effect of soil moisture on biomass-specific activity to community members' physiological acclimation or evolutionary adaptation of their populations, whereas enzyme stabilization might be only marginal. Although we acknowledge that more studies on enzyme turnover in different environmental conditions (Schimel et al., 2017) are necessary to be fully confident in our interpretation. These community members' acclimation/adaptation suggested by our results indicated a decrease of enzyme production under low soil moisture, and might result from a redirecting of the metabolism from resource acquisition to stress resistance (Schimel et al., 2007; Malik et al., 2019a). This finding stresses the potential importance of physiological acclimation and evolutionary adaptation of microbial traits under climate changes to predict future ecosystem functioning; an open question that urgently needs further experimental and modelling investigation (Romero-Olivares et al., 2015; Allison et al., 2018; Abs et al., 2019).

Overall, our results confirmed that microbial biomass is the first driver of the variation in total enzyme activity in soil under stable conditions, followed by community composition and community members' acclimation/evolution influencing biomass-specific activity, these two last mechanisms becoming especially important under altered climate scenarios. However, it is important to repeat that our study focused on potential and not realized in situ enzyme activity, with the latter being the results of both the potential activity and the in situ conditions (e.g. temperature, substrate diffusion, $\mathrm{pH}$ ). Thus, the development of a modelling approaches of realized in situ enzyme activity remains essential to fully link with ecosystem functioning (Wallenstein and Weintraub, 2008; Steinweg et al., 2012; Allison and Goulden, 2017).

\section{Conclusion and perspectives}

Our study showed that some enzymatic properties (mass-specific activity, enzymatic stoichiometry), considered as proxies of soil microbial CWM traits can be useful to assess the microbial adaptation to environmental variations and the mechanisms controlling ecosystem level total enzyme activity $\left(\mathrm{V}_{\max }\right)$. However, other enzymatic properties should also be considered in the light of the CWM traits concept, such as half saturation constant $\left(\mathrm{K}_{\mathrm{m}}\right)$, enzyme efficiency $\left(\mathrm{K}_{\mathrm{cat}}\right)$, enzyme temperature sensitivity $\left(\mathrm{Q}_{10}\right)$ and $\mathrm{pH}$ optimum. Studies assessing the response to environmental variations of these ecoenzymatic CWM traits (e.g. Bárta et al., 2014; German et al., 2012) and their relationships with microbial community composition (e.g. Tischer et al., 2015; Puissant et al., 2019), are highly valuable to move forward our understanding of microbial adaptation, community assembly and their links to ecosystem functioning.

Using a functional trait framework to design our study and interpret our results, we bring new insights on the mechanisms controlling total enzyme activity in soils. Our results indicate a tight association between microbial community composition and ecoenzymatic traits with important consequences for total enzyme activity at the ecosystem level. Our results also stress the relevance of approaches disentangling the effect of biomass and biomass-specific activity on microbially-mediated ecosystem processes (Billings and Ballantyne, 2013; Kivlin et al., 2013). We argue that empirical studies could develop a more mechanistic understanding by implementing this framework. Advancing our understanding of the roles of microbial traits in physiological acclimation, evolutionary adaptation, community composition changes, and ecosystem functioning should bring relevant insights to improve emerging microbial trait based models (Allison, 2012).

\section{Authors' contributions}

AF, KH, PS, GBDD and JCC designed the experiment together with other partners of the ECO-SERVE project. PMS, EN, FR and PS carried out the experiment in the Laboratory of Soil Ecology and Ecotoxicology 
of the University of Coimbra. All authors participated in sampling. GP, NL, JCC, AF conducted the enzymatic assays. KH measured the PLFA. LMG conducted the soil chemistry analyses. GP run all the statistical analyses, wrote the first draft of this paper and edited it based on significant comments from AF, LMG, NL, KH, GBDD and JCC. All authors gave final approval for publication.

\section{Declaration of competing interest}

The authors declare that they have no known competing financial interests or personal relationships that could have appeared to influence the work reported in this paper.

\section{Acknowledgements}

This work was funded by the ECO-SERVE project through the 2013-2014 BiodivERsA/FACCE-JPI joint call for research proposals, with the national funders ANR, NWO, FCT (BiodivERsA/001/2014), MINECO, FORMAS and SNF. EN was supported by CNPq - Brazil (CNPq Fellowship Holder - Brazil). The authors would like to thank Filipe Carvalho for its help in the maintenance of the experiment, and the farmers owning the field where the TMEs were extracted. The DOK trial from which the Swiss TMEs were extracted is funded by the Swiss Federal Office of Agriculture. GP was funded by the GlobNets (ANR-16CE02-0009) project from the French Agence Nationale de la Recherche (ANR) during the end of the redaction of this paper. We also thank anonymous referees for their detailed and insightful comments.

\section{References}

Abs, E., Saleska, S.R., Ferrière, R., Allison, S.D., 2019. Implications of microbial trait evolution for soil carbon-climate feedbacks at local and global scales. In: AGU Fall Meeting 2019. AGU.

Ackerly, D.D., 2003. Community assembly, niche conservatism, and adaptive evolution in changing environments. International Journal of Plant Sciences 164, S165-S184.

Allison, S., 2012. A trait-based approach for modelling microbial litter decomposition. Ecology Letters 15, 1058-1070.

Allison, S.D., Gartner, T.B., Holland, K., Weintraub, M., Sinsabaugh, R.L., 2007a. Soil Enzymes: Linking Proteomics and Ecological Processes, third ed. American Society of Microbiology. Pages 704-711 Manual of Environmental Microbiology.

Allison, S.D., Goulden, M.L., 2017. Consequences of drought tolerance traits for microbial decomposition in the DEMENT model. Soil Biology and Biochemistry 107 $104-113$.

Allison, S.D., Lu, L., Kent, A.G., Martiny, A.C., 2014. Extracellular enzyme production and cheating in Pseudomonas fluorescens depend on diffusion rates. Frontiers in Microbiology 5, 169.

Allison, S.D., Romero-Olivares, A.L., Lu, L., Taylor, J.W., Treseder, K.K., 2018. Temperature acclimation and adaptation of enzyme physiology in Neurospora discreta. Fungal Ecology 35, 78-86.

Allison, S.D., Weintraub, M.N., Gartner, T.B., Waldrop, M.P., 2010. Evolutionaryeconomic Principles as Regulators of Soil Enzyme Production and Ecosystem Function. Soil enzymology. Springer, pp. 229-243.

Allison, V., Condron, L., Peltzer, D., Richardson, S., Turner, B., 2007b. Changes in enzyme activities and soil microbial community composition along carbon and nutrient gradients at the Franz Josef chronosequence, New Zealand. Soil Biology and Biochemistry 39, 1770-1781.

Bárta, J., Šlajsová, P., Tahovská, K., Picek, T., Šantrcková, H., 2014. Different temperature sensitivity and kinetics of soil enzymes indicate seasonal shifts in C, N and P nutrient stoichiometry in acid forest soil. Biogeochemistry 117, 525-537.

Bell, C.W., Fricks, B.E., Rocca, J.D., Steinweg, J.M., McMahon, S.K., Wallenstein, M.D., 2013. High-throughput fluorometric measurement of potential soil extracellular enzyme activities. Journal of Visualized Experiments: Journal of Visualized Experiments 81. https://doi.org/10.3791/50961.

Bengtson, P., Bengtsson, G., 2007. Rapid turnover of DOC in temperate forests accounts for increased $\mathrm{CO} 2$ production at elevated temperatures. Ecology Letters 10, $783-790$.

Billings, S.A., Ballantyne, F., 2013. How interactions between microbial resource demands, soil organic matter stoichiometry, and substrate reactivity determine the direction and magnitude of soil respiratory responses to warming. Global Change Biology 19, 90-102.

Boer, W. de, Folman, L.B., Summerbell, R.C., Boddy, L., 2005. Living in a fungal world: impact of fungi on soil bacterial niche development. FEMS Microbiology Reviews 29, 795-811.

Burns, R.G., DeForest, J.L., Marxsen, J., Sinsabaugh, R.L., Stromberger, M.E., Wallenstein, M.D., Weintraub, M.N., Zoppini, A., 2013. Soil enzymes in a changing environment: current knowledge and future directions. Soil Biology and Biochemistry 58, 216-234.
Development Core Team, R.R, 2013. R: A Language and Environment for Statistical Computing. R Foundation for Statistical Computing.

Diaz, S., Lavorel, S., de Bello, F., Quétier, F., Grigulis, K., Robson, T.M., 2007. Incorporating plant functional diversity effects in ecosystem service assessments. Proceedings of the National Academy of Sciences 104, 20684-20689.

Fanin, N., Fromin, N., Buatois, B., Hättenschwiler, S., 2013. An experimental test of the hypothesis of non-homeostatic consumer stoichiometry in a plant litter-microbe system. Ecology Letters 16, 764-772.

Fanin, N., Kardol, P., Farrell, M., Nilsson, M.-C., Gundale, M.J., Wardle, D.A., 2018. The ratio of Gram-positive to Gram-negative bacterial PLFA markers as an indicator of carbon availability in organic soils. Soil Biology and Biochemistry 128, 111-114.

Fierer, N., Bradford, M.A., Jackson, R.B., 2007. Toward an ecological classification of soil bacteria. Ecology 88, 1354-1364.

Fierer, N., Jackson, R.B., 2006. The diversity and biogeography of soil bacterial communities. Proceedings of the National Academy of Sciences 103, 626-631.

Fierer, N., Lauber, C.L., Ramirez, K.S., Zaneveld, J., Bradford, M.A., Knight, R., 2012a. Comparative metagenomic, phylogenetic and physiological analyses of soil microbial communities across nitrogen gradients. The ISME Journal 6, 1007-1017.

Fierer, N., Leff, J.W., Adams, B.J., Nielsen, U.N., Bates, S.T., Lauber, C.L., Owens, S., Gilbert, J.A., Wall, D.H., Caporaso, J.G., 2012b. Cross-biome metagenomic analyses of soil microbial communities and their functional attributes. Proceedings of the National Academy of Sciences 109, 21390-21395.

Fontaine, S., Mariotti, A., Abbadie, L., 2003. The priming effect of organic matter: a question of microbial competition? Soil Biology and Biochemistry 35, 837-843.

Frankena, J., Van Verseveld, H., Stouthamer, A., 1988. Substrate and energy costs of the production of exocellular enzymes by Bacillus licheniformis. Biotechnology and Bioengineering 32, 803-812.

Frostegård, A., Bååth, E., 1996. The use of phospholipid fatty acid analysis to estimate bacterial and fungal biomass in soil. Biology and Fertility of Soils 22, 59-65.

Frostegård, Å., Bååth, E., Tunlio, A., 1993. Shifts in the structure of soil microbial communities in limed forests as revealed by phospholipid fatty acid analysis. Soil Biology and Biochemistry 25, 723-730.

Garnier, E., Cortez, J., Billès, G., Navas, M.-L., Roumet, C., Debussche, M., Laurent, G., Blanchard, A., Aubry, D., Bellmann, A., others, 2004. Plant functional markers capture ecosystem properties during secondary succession. Ecology 85, 2630-2637.

German, D.P., Marcelo, K.R., Stone, M.M., Allison, S.D., 2012. The Michaelis-Menten kinetics of soil extracellular enzymes in response to temperature: a cross-latitudinal study. Global Change Biology 18, 1468-1479.

Grace, J.B., Scheiner, S.M., Schoolmaster Jr., D.R., 2015. Structural equation modeling: building and evaluating causal models: chapter 8. In: Ecological Statistics: Contemporary Theory and Application 168-199. Oxford University Press, 2015.

Graham, E.B., Knelman, J.E., Schindlbacher, A., Siciliano, S., Breulmann, M., Yannarell, A., Beman, J., Abell, G., Philippot, L., Prosser, J., others, 2016. Microbes as engines of ecosystem function: when does community structure enhance predictions of ecosystem processes? Frontiers in Microbiology 7, 214.

Grime, J., 1998. Benefits of plant diversity to ecosystems: immediate, filter and founder effects. Journal of Ecology 86, 902-910.

Hertzog, L.R., 2018. How Robust Are Structural Equation Models to Model MissSpecification? A Simulation Study arXiv preprint arXiv:1803.06186.

Ho, A., Di Lonardo, D.P., Bodelier, P.L., 2017. Revisiting life strategy concepts in environmental microbial ecology. FEMS Microbiology Ecology 93 fix006.

Hodge, A., Robinson, D., Fitter, A., 2000. Are microorganisms more effective than plants at competing for nitrogen? Trends in Plant Science 5, 304-308.

Keiblinger, K.M., Hall, E.K., Wanek, W., Szukics, U., Hämmerle, I., Ellersdorfer, G., Böck, S., Strauss, J., Sterflinger, K., Richter, A., others, 2010. The effect of resource quantity and resource stoichiometry on microbial carbon-use-efficiency. FEMS Microbiology Ecology 73, 430-440.

Kirk, T.K., Farrell, R.L., 1987. Enzymatic" combustion": the microbial degradation of lignin. Annual Reviews in Microbiology 41, 465-501.

Kivlin, S.N., Waring, B.G., Averill, C., Hawkes, C.V., 2013. Tradeoffs in microbial carbon allocation may mediate soil carbon storage in future climates. Frontiers in Microbiology 4, 261.

Klamer, M., Båăth, E., 2004. Estimation of conversion factors for fungal biomass determination in compost using ergosterol and PLFA 18: 2๗6, 9. Soil Biology and Biochemistry 36, 57-65.

Knacker, T., van Gestel, C.A., Jones, S.E., Soares, A.M., Schallnaß, H.-J., Förster, B., Edwards, C.A., 2004. Ring-testing and field-validation of a Terrestrial Model Ecosystem (TME)-an instrument for testing potentially harmful substances: conceptual approach and study design. Ecotoxicology 13, 9-27.

Krause, S., Le Roux, X., Niklaus, P.A., Van Bodegom, P.M., Lennon, J.T., Bertilsson, S. Grossart, H.-P., Philippot, L., Bodelier, P.L., 2014. Trait-based approaches for understanding microbial biodiversity and ecosystem functioning. Frontiers in Microbiology 5, 251.

Kroppenstedt, R., 1985. Fatty acid and menaquinone analysis of actinomycetes and related organisms. Chemical Methods in Bacterial Systematics 173-199.

Lashermes, G., Gainvors-Claisse, A., Recous, S., Bertrand, I., 2016. Enzymatic strategies and carbon use efficiency of a litter-decomposing fungus grown on maize leaves, stems, and roots. Frontiers in Microbiology 7, 1315.

Lauber, C.L., Hamady, M., Knight, R., Fierer, N., 2009. Pyrosequencing-based assessment of soil $\mathrm{pH}$ as a predictor of soil bacterial community structure at the continental scale. Applied and Environmental Microbiology 75, 5111-5120.

Laughlin, D.C., Abella, S.R., Covington, W.W., Grace, J.B., 2007. Species richness and soil properties in Pinus ponderosa forests: a structural equation modeling analysis. Journal of Vegetation Science 18, 231-242. 
Laughlin, D.C., Strahan, R.T., Adler, P.B., Moore, M.M., 2018. Survival rates indicate that correlations between community-weighted mean traits and environments can be unreliable estimates of the adaptive value of traits. Ecology Letters 21, 411-421.

Lavorel, S., Garnier, E., 2002. Predicting changes in community composition and ecosystem functioning from plant traits: revisiting the Holy Grail. Functional Ecology 16, 545-556.

Lechevalier, M.P., Moss, C.W., 1977. Lipids in bacterial taxonomy-a taxonomist's view. CRC Critical Reviews in Microbiology 5, 109-210.

Lefcheck, J.S., 2016. piecewiseSEM: piecewise structural equation modelling in $\mathrm{r}$ for ecology, evolution, and systematics. Methods in Ecology and Evolution 7, 573-579.

Leff, J.W., Jones, S.E., Prober, S.M., Barberán, A., Borer, E.T., Firn, J.L., Harpole, W.S. Hobbie, S.E., Hofmockel, K.S., Knops, J.M., others, 2015. Consistent responses of soil microbial communities to elevated nutrient inputs in grasslands across the globe. Proceedings of the National Academy of Sciences 112, 10967-10972.

Li, Y., Nie, C., Liu, Y., Du, W., He, P., 2019. Soil microbial community composition closely associates with specific enzyme activities and soil carbon chemistry in a longterm nitrogen fertilized grassland. The Science of the Total Environment 654, 264-274.

Liang, C., Schimel, J.P., Jastrow, J.D., 2017. The importance of anabolism in microbial control over soil carbon storage. Nature Microbiology 2, 17105.

Litchman, E., Edwards, K.F., Klausmeier, C.A., 2015. Microbial resource utilization traits and trade-offs: implications for community structure, functioning, and biogeochemical impacts at present and in the future. Frontiers in Microbiology 6, 254.

Lladó, S., Žifcáková, L., Vetrovsk, T., Eichlerová, I., Baldrian, P., 2016. Functional screening of abundant bacteria from acidic forest soil indicates the metabolic potential of Acidobacteria subdivision 1 for polysaccharide decomposition. Biology and Fertility of Soils 52, 251-260.

López-Mondéjar, R., Algora, C., Baldrian, P., 2019. Lignocellulolytic systems of soil bacteria: a vast and diverse toolbox for biotechnological conversion processes. Biotechnology Advances 37 (6).

Lori, M., Piton, G., Symanczik, S., Legay, N., Brussaard, L., Jaenicke, S., Nascimento, E. Reis, F., Sousa, J.P., Mäder, P., others, 2020. Compared to conventional, ecological intensive management promotes beneficial proteolytic soil microbial communities for agro-ecosystem functioning under climate change-induced rain regimes. Scientific Reports 10, 1-15.

Malik, A.A., Martiny, J.B., Brodie, E.L., Martiny, A.C., Treseder, K.K., Allison, S.D. 2019a. Defining trait-based microbial strategies with consequences for soil carbon cycling under climate change. The ISME Journal 1-9.

Malik, A.A., Puissant, J., Goodall, T., Allison, S.D., Griffiths, R.I., 2019b. Soil microbial communities with greater investment in resource acquisition have lower growth yield. Soil Biology and Biochemistry 132, 36-39.

Malik, A.A., Swenson, T., Weihe, C., Morrison, E., Martiny, J.B., Brodie, E.L., Northen, T. R., Allison, S.D., 2019c. Physiological adaptations of leaf litter microbial communities to long-term drought. BioRxiv 631077.

Manoharan, L., Kushwaha, S.K., Ahrén, D., Hedlund, K., 2017. Agricultural land use determines functional genetic diversity of soil microbial communities. Soil Biology and Biochemistry 115, 423-432.

Martinez-Almoyna, C., Thuiller, W., Chalmandrier, L., Ohlmann, M., Foulquier, A., Clément, J.-C., Zinger, L., Münkemüller, T., 2019. Multi-trophic $\beta$-diversity mediates the effect of environmental gradients on the turnover of multiple ecosystem functions. Functional Ecology 33 (10), 2053-2064.

Martiny, J.B., Jones, S.E., Lennon, J.T., Martiny, A.C., 2015. Microbiomes in light of traits: a phylogenetic perspective. Science 350, aac9323.

Moorhead, D.L., Rinkes, Z.L., Sinsabaugh, R.L., Weintraub, M.N., 2013. Dynamic relationships between microbial biomass, respiration, inorganic nutrients and enzyme activities: informing enzyme-based decomposition models. Frontiers in Microbiology 4, 223.

Mooshammer, M., Wanek, W., Zechmeister-Boltenstern, S., Richter, A., 2014. Stoichiometric imbalances between terrestrial decomposer communities and their resources: mechanisms and implications of microbial adaptations to their resources. The Microbial Regulation of Global Biogeochemical Cycles 191.

Nannipieri, P., Trasar-Cepeda, C., Dick, R.P., 2018. Soil enzyme activity: a brief history and biochemistry as a basis for appropriate interpretations and meta-analysis. Biology and Fertility of Soils 54, 11-19.

Naylor, D., Coleman-Derr, D., 2018. Drought stress and root-associated bacterial communities. Frontiers of Plant Science 8, 2223.

Ng, E., Bandow, C., Proença, D., Santos, S., Guilherme, R., Morais, P., Römbke, J., Sousa, J., 2014. Does altered rainfall regime change pesticide effects in soil? A terrestrial model ecosystem study from Mediterranean Portugal on the effects of pyrimethanil to soil microbial communities under extremes in rainfall. Applied Soil Ecology 84, 245-253.

O'leary, W., Wilkinson, S., 1988. Gram-positive bacteria. Microbial Lipids 1, 117-201.

Olsson, P.A., Bååth, E., Jakobsen, I., Söderström, B., 1995. The use of phospholipid and neutral lipid fatty acids to estimate biomass of arbuscular mycorrhizal fungi in soil. Mycological Research 99, 623-629.

Paradis, E., Schliep, K., 2019. Ape 5.0: an environment for modern phylogenetics and evolutionary analyses in R. Bioinformatics $35,526-528$

Petchey, O.L., Gaston, K.J., 2006. Functional diversity: back to basics and looking forward. Ecology Letters 9, 741-758.

Pierre-Emmanuel, C., François, M., Marc-André, S., Myriam, D., Stéven, C., Fabio, Z., Marc, B., Claude, P., Adrien, T., Jean, G., others, 2016. Into the functional ecology of ectomycorrhizal communities: environmental filtering of enzymatic activities. Journal of Ecology 104, 1585-1598.

Pinheiro, J., Bates, D., DebRoy, S., Sarkar, D., Team, R.C., 2017. Nlme: Linear and Nonlinear Mixed Effects Models (R Package Version 3.1-128, 2016). R software.
Piton, G., Legay, N., Arnoldi, C., Lavorel, S., Clément, J.C., Foulquier, A., 2020. Using proxies of microbial community-weighted means traits to explain the cascading effect of management intensity, soil and plant traits on ecosystem resilience in mountain grasslands. Journal of Ecology 108 (3), 876-893.

Puissant, J., Jones, B., Goodall, T., Mang, D., Blaud, A., Gweon, H.S., Malik, A., Jones, D. L., Clark, I.M., Hirsch, P.R., others, 2019. The pH optimum of soil exoenzymes adapt to long term changes in soil pH. Soil Biology and Biochemistry 138, 107601.

Ramin, K.I., Allison, S.D., 2019. Bacterial tradeoffs in growth rate and extracellular enzymes. Frontiers in Microbiology 10, 2956.

Ren, C., Zhang, W., Zhong, Z., Han, X., Yang, G., Feng, Y., Ren, G., 2018. Differential responses of soil microbial biomass, diversity, and compositions to altitudinal gradients depend on plant and soil characteristics. The Science of the Total Environment 610, 750-758.

Romani, A.M., Fischer, H., Mille-Lindblom, C., Tranvik, L.J., 2006. Interactions of bacteria and fungi on decomposing litter: differential extracellular enzyme activities. Ecology 87, 2559-2569.

Romero-Olivares, A.L., Taylor, J.W., Treseder, K.K., 2015. Neurospora discreta as a model to assess adaptation of soil fungi to warming. BMC Evolutionary Biology 15, 198.

Rosinger, C., Rousk, J., Sandén, H., 2019. Can enzymatic stoichiometry be used to determine growth-limiting nutrients for microorganisms?-A critical assessment in two subtropical soils. Soil Biology and Biochemistry 128, 115-126.

Schimel, J., Balser, T.C., Wallenstein, M., 2007. Microbial stress-response physiology and its implications for ecosystem function. Ecology 88, 1386-1394.

Schimel, J., Becerra, C.A., Blankinship, J., 2017. Estimating decay dynamics for enzyme activities in soils from different ecosystems. Soil Biology and Biochemistry 114, $5-11$.

Schimel, J.P., Bennett, J., 2004. Nitrogen mineralization: challenges of a changing paradigm. Ecology 85, 591-602.

Schmidt, M.W., Torn, M.S., Abiven, S., Dittmar, T., Guggenberger, G., Janssens, I.A Kleber, M., Kögel-Knabner, I., Lehmann, J., Manning, D.A., others, 2011. Persistence of soil organic matter as an ecosystem property. Nature 478, 49.

Shipley, B., 2000. A new inferential test for path models based on directed acyclic graphs. Structural Equation Modeling 7, 206-218.

Shipley, B., 2003. Testing recursive path models with correlated errors using dseparation. Structural Equation Modeling 10, 214-221.

Shipley, B., 2009. Confirmatory path analysis in a generalized multilevel context. Ecology 90, 363-368.

Shipley, B., 2016. Cause and Correlation in Biology: a User's Guide to Path Analysis, Structural Equations and Causal Inference with R. Cambridge University Press.

Shipley, B., Vile, D., Garnier, É., 2006. From plant traits to plant communities: a statistical mechanistic approach to biodiversity. Science 314, 812-814.

Sinsabaugh, R.L., 2005. Fungal enzymes at the community scale. Mycology Series 23, 349.

Sinsabaugh, R.L., Antibus, R., Linkins, A., McClaugherty, C., Rayburn, L., Repert, D. Weiland, T., 1993. Wood decomposition: nitrogen and phosphorus dynamics in relation to extracellular enzyme activity. Ecology 74, 1586-1593.

Sinsabaugh, R.L., Follstad Shah, J.J., 2012. Ecoenzymatic stoichiometry and ecological theory. Annual Review of Ecology, Evolution and Systematics 43, 313-343.

Sinsabaugh, R.L., Hill, B.H., Shah, J.J.F., 2009. Ecoenzymatic stoichiometry of microbial organic nutrient acquisition in soil and sediment. Nature 462, 795-798.

Steinweg, J.M., Dukes, J.S., Paul, E.A., Wallenstein, M.D., 2013. Microbial responses to multi-factor climate change: effects on soil enzymes. Frontiers in Microbiology 4, 146.

Steinweg, J.M., Dukes, J.S., Wallenstein, M.D., 2012. Modeling the effects of temperature and moisture on soil enzyme activity: linking laboratory assays to continuous field data. Soil Biology and Biochemistry 55, 85-92.

Strickland, M.S., Rousk, J., 2010. Considering fungal: bacterial dominance in soils-methods, controls, and ecosystem implications. Soil Biology and Biochemistry 42, 1385-1395.

Tischer, A., Blagodatskaya, E., Hamer, U., 2015. Microbial community structure and resource availability drive the catalytic efficiency of soil enzymes under land-use change conditions. Soil Biology and Biochemistry 89, 226-237.

Trivedi, P., Anderson, I.C., Singh, B.K., 2013. Microbial modulators of soil carbon storage: integrating genomic and metabolic knowledge for global prediction. Trends in Microbiology 21, 641-651.

Velthorst, E., 1993. Manual for Chemical Water Analyses. Department of Soil Science and Geology, Agricultural University.

Violle, C., Navas, M.-L., Vile, D., Kazakou, E., Fortunel, C., Hummel, I., Garnier, E., 2007. Let the concept of trait be functional! Oikos 116, 882-892.

Vranova, V., Rejsek, K., Formanek, P., 2013. Proteolytic activity in soil: a review. Applied Soil Ecology 70, 23-32.

De Vries, F.T., Bardgett, R.D., 2016. Plant community controls on short-term ecosystem nitrogen retention. New Phytologist 210, 861-874.

De Vries, F.T., Hoffland, E., van Eekeren, N., Brussaard, L., Bloem, J., 2006. Fungal/ bacterial ratios in grasslands with contrasting nitrogen management. Soil Biology and Biochemistry 38, 2092-2103.

De Vries, F.T., Manning, P., Tallowin, J.R., Mortimer, S.R., Pilgrim, E.S., Harrison, K.A., Hobbs, P.J., Quirk, H., Shipley, B., Cornelissen, J.H., others, 2012. Abiotic drivers and plant traits explain landscape-scale patterns in soil microbial communities. Ecology Letters 15, 1230-1239.

Wallenstein, M.D., Weintraub, M.N., 2008. Emerging tools for measuring and modeling the in situ activity of soil extracellular enzymes. Soil Biology and Biochemistry 40, 2098-2106.

Wilkinson, S., 1988. Gram-negative bacteria. Microbial Lipids 1, 299-488. 
Xu, Z., Yu, G., Zhang, X., He, N., Wang, Q., Wang, S., Wang, R., Zhao, N., Jia, Y., Wang, C., 2017. Soil enzyme activity and stoichiometry in forest ecosystems along the North-South Transect in eastern China (NSTEC). Soil Biology and Biochemistry 104, 152-163.

Zechmeister-Boltenstern, S., Keiblinger, K.M., Mooshammer, M., Peñuelas, J., Richter, A., Sardans, J., Wanek, W., 2015. The application of ecological stoichiometry to plant-microbial-soil organic matter transformations. Ecological Monographs 85, 133-155.

Zelles, L., 1997. Phospholipid fatty acid profiles in selected members of soil microbial communities. Chemosphere 35, 275-294.

Žifcáková, L., Vetrovsk, T., Lombard, V., Henrissat, B., Howe, A., Baldrian, P., 2017. Feed

in summer, rest in winter: microbial carbon utilization in forest topsoil. Microbiome 5,122 . 